\title{
Do Bioactive Food Compound with Avena sativa L., Linum usitatissimum L. and Glycine max L. Supplementation with Moringa oleifera Lam. Have a Role against Nutritional Disorders? An Overview of the In Vitro and In Vivo Evidence
}

\author{
Rosângela dos Santos Ferreira ${ }^{1}$ (D) , Lígia Aurélio Bezerra Maranhão Mendonça ${ }^{1} \mathbb{D}$, Cristiane dos Santos ${ }^{1}$, \\ Priscila Aiko Hiane ${ }^{2} \mathbb{D}$, Rosemary Matias ${ }^{3}$, Octávio Luiz Franco ${ }^{1,4} \mathbb{D}^{\mathbb{D}}$, Ademir Kleber Morbeck de Oliveira ${ }^{3} \mathbb{D}$, \\ Valter Aragão do Nascimento ${ }^{2}$, Arnildo Pott ${ }^{5}$ (D), Cristiano Marcelo Espinola Carvalho ${ }^{1}$ (D) \\ and Rita de Cássia Avellaneda Guimarães ${ }^{2, *}$
}

1 Graduate Program in Biotechnology, S-Inova Biotech, Catholic University Dom Bosco-UCDB, Campo Grande 79117-010, MS, Brazil; rosangela.ferreira@ufms.br (R.d.S.F.); lmendoncanutri@gmail.com (L.A.B.M.M.); cristinyba@gmail.com (C.d.S.); ocfranco@gmail.com (O.L.F.); cristiano@ucdb.br (C.M.E.C.)

check for updates

Citation: Ferreira, R.d.S.; Mendonça, L.A.B.M.; Santos, C.d.; Hiane, P.A.; Matias, R.; Franco, O.L.; de Oliveira, A.K.M.; do Nascimento, V.A.; Pott, A.; Carvalho, C.M.E.; et al. Do Bioactive Food Compound with Avena sativa L., Linum usitatissimum $\mathrm{L}$. and Glycine $\max$ L. Supplementation with Moringa oleifera Lam. Have a Role against Nutritional Disorders? An Overview of the In Vitro and In Vivo Evidence. Nutrients 2021, 13, 2294. https: / / doi.org/10.3390/nu13072294

Academic Editor: Matteo Tosato

Received: 13 May 2021

Accepted: 21 June 2021

Published: 2 July 2021

Publisher's Note: MDPI stays neutral with regard to jurisdictional claims in published maps and institutional affiliations.

Copyright: (c) 2021 by the authors. Licensee MDPI, Basel, Switzerland. This article is an open access article distributed under the terms and conditions of the Creative Commons Attribution (CC BY) license (https:/ / creativecommons.org/licenses/by/ $4.0 /)$.
2 Graduate Program in Health and Development in the Central-West Region of Brazil, Federal University of Mato Grosso do Sul-UFMS, Campo Grande 79079-900, MS, Brazil; priscila.hiane@ufms.br (P.A.H.); aragao60@hotmail.com (V.A.d.N.)

3 Graduate Program in Environment and Regional Development, University Anhanguera Uniderp, Campo Grande 79035-470, MS, Brazil; mdr@anhanguera.com (R.M.); akmorbeckoliveira@gmail.com (A.K.M.d.O.)

4 Graduate Program in Genomic Sciences and Biotechnology, Center of Proteomic and Biochemical Analysis, Catholic University of Brazilia, Brasília 70790-160, DF, Brazil

5 Institute of Biosciences, Federal University of Mato Grosso do Sul-UFMS, Campo Grande 79079-900, MS, Brazil; arnildo.pott@gmail.com

* Correspondence: ritaaguimaraes@gmail.com

Abstract: Functional clinical nutrition is an integrative science; it uses dietary strategies, functional foods and medicinal plants, as well as combinations thereof. Both functional foods and medicinal plants, whether associated or not, form nutraceuticals, which can bring benefits to health, in addition to being included in the prevention and treatment of diseases. Some functional food effects from Avena sativa L. (oats), Linum usitatissimum L. (brown flaxseed), Glycine max L. (soya) and Moringa oleifera have been proposed for nutritional disorders through in vitro and in vivo tests. A formulation called a bioactive food compound (BFC) showed efficiency in the association of oats, flaxseed and soy for dyslipidemia and obesity. In this review, we discuss the effects of BFC in other nutritional disorders, as well as the beneficial effects of M. oleifera in obesity, cardiovascular disease, diabetes mellitus type 2, metabolic syndrome, intestinal inflammatory diseases/colorectal carcinogenesis and malnutrition. In addition, we hypothesized that a BFC enriched with $M$. oleifera could present a synergistic effect and play a potential benefit in nutritional disorders. The traditional consumption of $M$. oleifera preparations can allow associations with other formulations, such as BFC. These nutraceutical formulations can be easily accepted and can be used in sweet preparations (fruit and/or vegetable juices, fruit and/or vegetable vitamins, porridges, yogurt, cream, mousses or fruit salads, cakes and cookies) or savory (vegetable purees, soups, broths and various sauces), cooked or not. These formulations can be low-cost and easy-to-use. The association of bioactive food substances in dietary formulations can facilitate adherence to consumption and, thus, contribute to the planning of future nutritional interventions for the prevention and adjuvant treatment of the clinical conditions presented in this study. This can be extended to the general population. However, an investigation through clinical studies is needed to prove applicability in humans.

Keywords: oat; flaxseed; soya; M. oleifera; nutraceuticals; non-transmissible chronical diseases; intestinal inflammatory diseases; malnutrition; intestinal microbiota 


\section{Introduction}

The growing escalation of non-transmissible chronic diseases (NTCD), intestinal inflammatory diseases (IID) and malnutrition has raised much concern in the general public and in public agencies related to nutrition and health. Taking into account that people affected by such diseases need a better quality of life, dietary intervention based on functional foods and nutraceutical medicinal plants are very important [1-3].

In this context, functional clinical nutrition arises, which is an integrative science, meaning it seeks aiming to understand the communication among all biological systems and to act in the prevention or treatment of organic imbalances. The clinical practice takes into account genetic and biochemical individuality, whereby functional foods, as well as medicinal plants and their combination, are utilized as dietary strategies [2,4-8].

Both functional foods and medicinal plants, whether associated or not, form nutraceuticals, which can bring benefits to health, besides being included in the prevention and treatment of diseases. Nutraceuticals contain isolated components, such as dietary fibers, poly-unsaturated fatty acids (PUFAs), proteins, peptides, amino acids, vitamins and antioxidant minerals, as well as dietary supplements consumed in different forms [1,9-11].

Nutraceuticals based on functional foods exert favorable effects, combining substances with bioactive activities, besides influencing health maintenance and correcting metabolic disorders, reducing the risk of diseases [12-14]. Nutraceuticals derived from medicinal plants utilize the pharmacological basis of botanical species, also with therapeutical coadjuvant purposes, and can be combined with functional foods, as part of a single nutraceutical formulation [15].

Non-Transmissible Chronic Diseases (NTCDs) (obesity, cardiovascular disease and diabetes mellitus type 2 (DM2)), metabolic syndrome (MS), IID (intestinal inflammatory diseases)/colorectal carcinogenesis (CRC) and malnutrition have a close relationship with the metabolic-nutritional state (Figure 1).

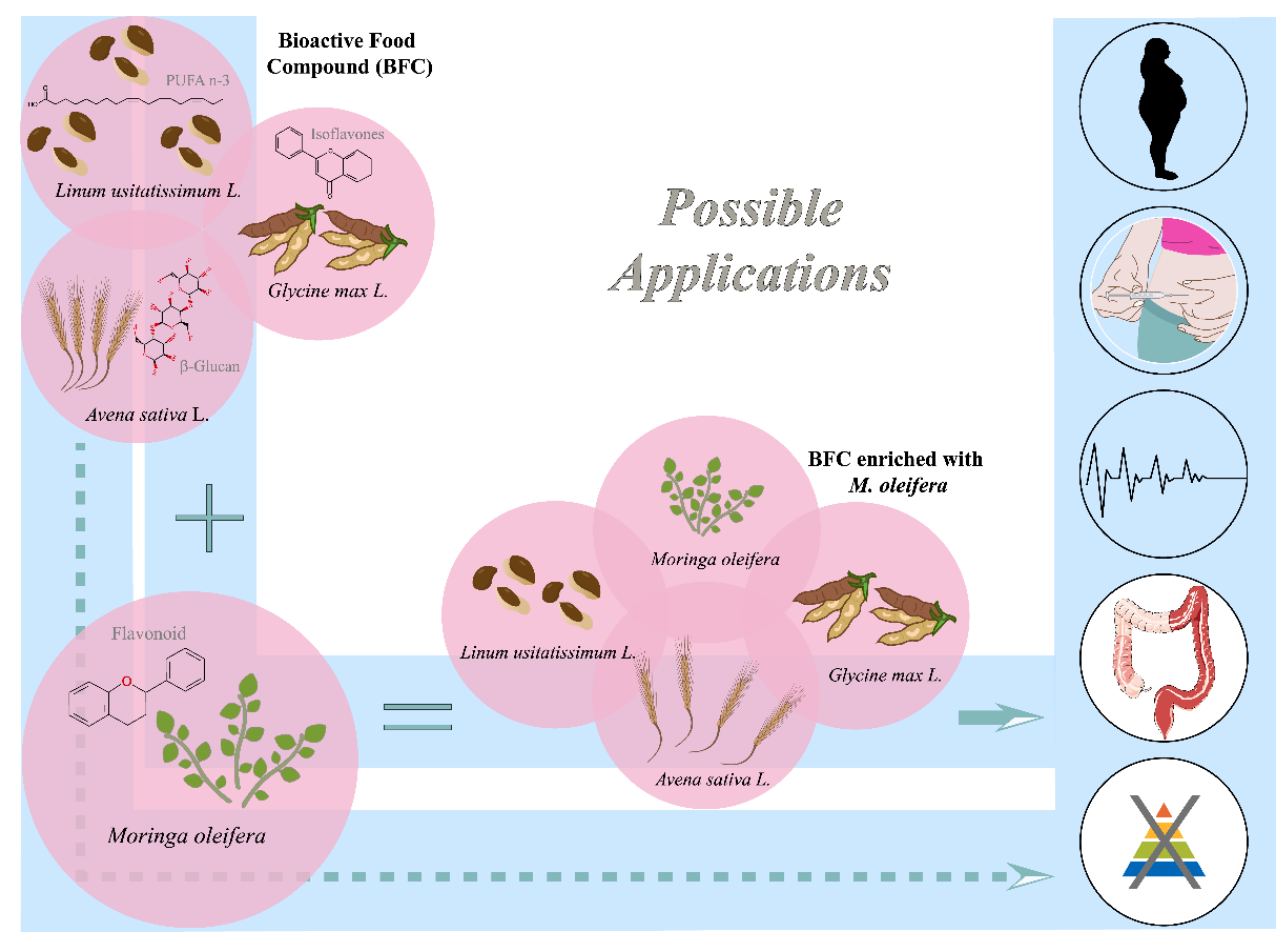

Figure 1. The nutritional and phytochemical composition of a bioactive food compound (BFC), M. oleifera and a BFC enriched with M. oleifera in NTCDs, IID and malnutrition.

Some effects from functional foods, such as Avena sativa L. (oats), Linum usitatissimum L. (brown flaxseed), Glycine max L. (soya) and Moringa oleifera, have been presented for nutritional disorders through in vitro and in vivo tests [16-20], NCT04314258 (Tables 1 and 2). 
In the literature, there is vast knowledge of the benefits of these functional foods. However, a formulation, called a bioactive food compound (BFC), showed efficiency in the association of oats, flaxseed and soy for dyslipidemia and obesity [17,18].

Table 1. BFC and M. oleifera nutraceutical bioactivity in clinical trials.

\begin{tabular}{|c|c|c|}
\hline Physiological and Metabolic Effects & Population/Treatment Time/Applied Dose & References \\
\hline \multicolumn{3}{|l|}{ Oat } \\
\hline$\beta$-glucans reduced mean LDL-C and TC levels & $\begin{array}{l}83 \text { participants, } 8 \text { weeks, boxes containing } \\
28 \text { sachets, } 3 \mathrm{~g} \beta \text {-glucans }\end{array}$ & [21] \\
\hline Reduced LDL and TC levels & $28 \mathrm{RCTs}, \geq 3 \mathrm{~g} /$ day, food products, $\geq 2$ weeks & [22] \\
\hline $\begin{array}{l}\text { Reduced glucose, TC, triglycerides and BMI and } \\
\text { waist-hip ratio }\end{array}$ & $\begin{array}{l}30 \text { participants with MS, } 37.26 \text { years / } 8 \text { weeks / } \\
15 \mathrm{~g} / \text { day fiber intake oat bran }\end{array}$ & [23] \\
\hline Improved nutritional status & $\begin{array}{c}1406 \text { children between } 6 \text { and } 59 \text { months of age } \\
\text { with uncomplicated SAM/12 weeks/30 g } \\
\text { oat-RUTF }\end{array}$ & [24] \\
\hline \multicolumn{3}{|l|}{ Flaxseed } \\
\hline GF and FO attenuated systemic inflammation & $\begin{array}{l}75 \text { patients with UC, GF ( } 30 \mathrm{~g} / \text { day }) \text { and FO } \\
\text { (10 g/day), } 12 \text { weeks }\end{array}$ & [25] \\
\hline Patients with mild to moderately severe UC & $\begin{array}{l}18 \text { years and over, phase } 2, \text { FLC, } 300 \text { mg FLC, } \\
12 \text { week }\end{array}$ & NCT02201758 \\
\hline $\begin{array}{l}\text { Effective in amelioration of some symptoms of } \\
\text { MS and decrease BP and lipid peroxidation }\end{array}$ & $\begin{array}{c}60 \text { participants/aged } 30 \text { to } 60 \text { years } / 25 \mathrm{~mL} / \mathrm{d} \\
\text { FO/7 week }\end{array}$ & [26] \\
\hline
\end{tabular}

\section{Soya}

Add genistein FOLFOX or

FOLFOX-Bevacizumab. Efficacy results are notable

Reduced risk for overall colorectal cancer
13 participants metastatic colorectal cancer, 7 days, 2 weeks

901 participants with colorectal cancer, 2669 participants as control, high intake of total soy products or dietary isoflavones

Added genistein to the regimens of FOLFOX or Participants with metastatic (stage IV) colorectal FOLFOX-Avastin cancer, Phase 2

1546 children aged 6-23 months/ 1 month of

Soybean fortified meal improved the nutritional status of the children malnutrition supplementation $/ 3$ meals per day with $40 \mathrm{~g}$ CSB per meal

Nutrition in the management of HIV / AIDS. Higher total blood protein, blood white protein, level of blood hemoglobin and higher CD4 cell count

47 PLWHAs/Nutritional and intervention Education Program/100 g soybean/day

\section{Moringa oleifera}

Decreased postprandial glucose response. $M$. oleifera leaf powder could be a hypoglycemic herbal drug
17 Saharawi diabetics and 10 healthy subjects, $20 \mathrm{~g}$ of M. oleifera leaf powder
M. oleifera infusion effect in hot water twice daily on the blood glucose plasma lipids level and blood anti-oxidant status. Comparison of the lipid profiles of both healthy and hyperglycemic RCS, 18-65 years (adult, older adult), 103 participants - M. oleifera leaves infused 
Table 1. Cont.

\begin{tabular}{|c|c|c|}
\hline Physiological and Metabolic Effects & Population/Treatment Time/Applied Dose & References \\
\hline $\begin{array}{c}\text { Investigation of the effects of } M \text {. oleifera } \\
\text { supplementation on the levels of inflammatory } \\
\text { markers, specifically the hsCRP, hgbA1c level } \\
\text { and clinical outcome in diabetic patients through } \\
\text { a cohort study }\end{array}$ & 56 participants, supplementation of M. oleifera & NCT02308683 \\
\hline $\begin{array}{l}\text { Potential lowering effect on both SBP and DBP, } \\
\text { postprandial follow-up }\end{array}$ & $\begin{array}{c}41 \text { healthy participants, } 120 \mathrm{~g} \text { of cooked } M \text {. } \\
\text { oleifera leaves }\end{array}$ & [31] \\
\hline $\begin{array}{l}\text { Glycemic control and no adverse effects in T2DM. } \\
\text { Tendency on blood pressure reduction in T2DM }\end{array}$ & $\begin{array}{l}\text { Therapy-naïve T2DM with the duration of } \\
\text { diabetes of less than } 5 \text { years, } 20-70 \text { years, } 8 \mathrm{~g} \text {, day, } \\
40 \text { days of } M \text {. oleifera leaf capsules }\end{array}$ & [32] \\
\hline $\begin{array}{l}\text { Increased insulin secretion, potential agent in the } \\
\text { treatment of type } 2 \text { diabetes }\end{array}$ & $\begin{array}{c}10 \text { healthy subjects, } 24-34 \text { years, } 4 \mathrm{~g} \text { capsules } \\
\text { M. oleifera leaf powder }\end{array}$ & [33] \\
\hline Antipyretic effects & $\begin{array}{c}\text { A CS, an 18-month-old girl, } 40 \mathrm{~mL} \text { of warm } \\
\text { water extract of } 5 \mathrm{~g}\end{array}$ & [34] \\
\hline $\begin{array}{c}\text { Investigated weight gain and hemoglobin and } \\
\text { vitamin A status }\end{array}$ & $\begin{array}{l}\text { Adolescent girls, } 150 \mathrm{gm} \text { of Sajna shak/bora } \\
\text { (Moringa) } 5 \text { days/week/ } 6 \text { months }\end{array}$ & NCT04156321 \\
\hline Reduction in anemia cases & $\begin{array}{l}95 \text { anemic children } / 200 \mathrm{~g} / \mathrm{m} / \mathrm{M} \text {. oleifera leaf } \\
\text { powder } / 6 \text { months }\end{array}$ & [35] \\
\hline $\begin{array}{l}\text { M. oleifera improved parameters associated with } \\
\text { obese-DM2 }\end{array}$ & $\begin{array}{l}24 \text { obese DM2/17 women and } 7 \text { men, } \\
20-60 y / 22 w \text { M. oleifera leaves }\end{array}$ & [36] \\
\hline $\begin{array}{l}\text { To evaluate the in vivo bioavailability of key } \\
\text { nutrients and bioactives and biological activities } \\
\text { of the leaves, malnourishment prevention }\end{array}$ & $\begin{array}{c}10 \text { participants/18 Years and older (Adult, Older } \\
\text { Adult)/Healthy males or females/corn Moringa } \\
\text { Diet }\end{array}$ & NCT04092517 \\
\hline \multicolumn{3}{|c|}{$\begin{array}{l}\text { BMI-Body Mass Index; BP - Blood Pressure; CD4-Cluster of Differentiation 4; CS-Case Study; CSB-corn-soy blends; FLC-Flaxseed } \\
\text { Lignan-enriched Complex; FO-Flaxseed Oili GF-Grounded Flaxseed; HIV/AIS-CHuman Immunodeficiency Virus/Acquired Immun- } \\
\text { odeficiency Syndrome; LDL-C-Low Density Lipoproteins-Cholesterol; MS-Metabolic Syndrome; ML M. oleifera leaves; MS-M. oleifera } \\
\text { seeds. PLWHAs-people living with HIV/AIDS; RCS-Randomized Clinical Study; RCT-Randomized Controlled Trials; SAM-Severe } \\
\text { Acute Malnutrition; T2DM-Type 2 Diabetes Mellitus; TC-Total Cholesterol; UC-Ulcerative Colitis; High sensitivity C-reactive protein } \\
\text { (hsCRP); systolic blood pressure (SBP); diastolic blood pressure (DBP); and HbA1c (Hemoglobin A1c). }\end{array}$} \\
\hline
\end{tabular}

Table 2. BFC and M. oleifera nutraceutical bioactivity: in vitro and animal model bioassays.

\begin{tabular}{ccc}
\hline Physiological and Metabolic Effects & Population/Treatment Time/Applied Dose & References \\
\hline Oat & Wistar-Lewis male rats-30 days/oat flake & \\
Hypolipidemic & $\begin{array}{c}\text { powders: dose of } 5 \mathrm{~g} \mathrm{~kg}^{-1} \text { body weight per day. } \\
\beta \text {-glucan extracted and purified dose of } 0.3 \mathrm{~g} \mathrm{~kg}^{-1}\end{array}$ & [37] \\
body weight per day
\end{tabular}

Flaxseed

Reducing goblet cell depletion, scavenging oxygen-derived free radicals, reduce neutrophil

infiltration that may be attributed due to decreasing IFN- $\gamma$ and TNF- $\alpha$ and increasing IL-17

$\mathrm{BALB} / \mathrm{c}$ mice induced colitis/ 6 days $/ 150,300$ and $500 \mathrm{mg} / \mathrm{kg} /$ day

levels 
Table 2. Cont.

\begin{tabular}{|c|c|c|}
\hline Physiological and Metabolic Effects & Population/Treatment Time/Applied Dose & References \\
\hline $\begin{array}{c}\text { Antihyperglycemic effect mediated through } \\
\text { inhibition of ROS }\end{array}$ & $\begin{array}{l}\text { Male Wistar rats / } 21 \text { days } / 200 \text { and } \\
400 \mathrm{mg} / \mathrm{kg} / \text { EELU }\end{array}$ & {$[40]$} \\
\hline $\begin{array}{c}\text { Improved glucose utilization; increased } \\
\text { glucose-6-phosphate dehydrogenase; reduction of } \\
\text { PPHG }\end{array}$ & Male Swiss mice/21 days/2, $1 \mathrm{mg}$ flaxseed powder & [41] \\
\hline $\begin{array}{l}\text { Alters the baseline colonic microenvironment of } \\
\text { healthy mice, which may modify subsequent } \\
\text { mucosal microbial defense and injury-repair } \\
\text { responses leading to altered susceptibility to } \\
\text { different gut-associated diseases }\end{array}$ & C57Bl $/ 6$ male mice $/ 3$ weeks $/ 10 \%$ flaxseed & {$[42]$} \\
\hline \multicolumn{3}{|l|}{ Soya } \\
\hline $\begin{array}{l}\text { Decreased body weight and the plasma TG and } \\
\text { LDL concentrations. Decreased in activity of } \\
\text { mTORC1. Suppressed lipogenesis and } \\
\text { adipogenesis, potential mechanism of soy } \\
\text { isoflavones regulating lipid homeostasis. }\end{array}$ & $\begin{array}{l}64 \text { Male rats } / 4 \text { weeks / Basal diets }+50 \mathrm{mg} / \mathrm{kg} \text {; } \\
150 \mathrm{mg} / \mathrm{kg} ; 400 \mathrm{mg} / \mathrm{kg} \text { doses of soy isoflavones }\end{array}$ & [43] \\
\hline $\begin{array}{l}\text { Reduced the body weight gain and related } \\
\text { biomarkers. Fat deposits, dyslipidemia, } \\
\text { hyperglycemia and fatty liver were ameliorated by } \\
\text { dietary genistein. }\end{array}$ & $\begin{array}{l}\text { Male C57BL / 6J mice / }(n=15,16 \text { weeks) } 0.25 \% \\
\text { genistein (Study } 1 \text { ) and ( } n=75,18 \text { weeks) } 0.2 \% \text { and } \\
0.067 \% \text { (Study } 2 \text { ) dose-response effect of genistein }\end{array}$ & [44] \\
\hline $\begin{array}{l}\text { Altered the microbial composition and modulated } \\
\text { the metabolic pathway of the microbial } \\
\text { metabolism in the colon. Serum levels of IgG and } \\
\text { IgM were significantly increased in FF group pigs } \\
\text { ( } p<0.05) \text {. FF significantly decreased the } \\
\text { abundances of Bacteroides and Verrucomicrobia in } \\
\text { the duodenum and decreased the abundances of } \\
\text { Bacteroides, Proteobacteria and Verrucomicrobiain } \\
\text { in the colon and significantly increased the } \\
\text { abundances of Firmicutes and Actinobacteria } \\
(p<0.05) \text {. Serum immunity and expression of } \\
\text { genes related to gut immunity were associated } \\
\text { with bacterial strains at the family level }\end{array}$ & $\begin{array}{l}48 \text { growing barrow pigs } / 2 \text { feeding groups }(n=24 \\
\text { each, UF and FF) }\end{array}$ & [45] \\
\hline
\end{tabular}

\section{Moringa oleifera}

Antioxidant, hypolipidemic and antiatherosclerotic activities, $(p<0.05)$ lowered the cholesterol levels and reduced the atherosclerotic plaque formation to about $50 \%$ and $86 \%$, respectively

\begin{tabular}{ccc}
\hline $\begin{array}{c}\text { Anti-cancer activity/MDA-MB-231 and HCT-8 } \\
\text { cancer cell lines }\end{array}$ & $\begin{array}{c}\text { In vitro/250 mg of extracts were dissolved in } \\
1.0 \mathrm{~mL} \text { of ethanol }\end{array}$ & [47] \\
\hline $\begin{array}{c}\text { Prevention of cognitive damage due to chronic } \\
\text { hyperglycemia and oxidative stress }\end{array}$ & 88 Wistar rats/14 days/2 e 4\% de ML/MS. & [48] \\
\hline $\begin{array}{c}\text { Moringa leaf extract reversed hepatic insulin } \\
\text { insensitivity, up-regulation of genes involved in } \\
\text { insulin receptors and glucose uptake in the liver }\end{array}$ & $\begin{array}{c}10 \text { hyperinsulinemic male rats } / 4 \text { weeks/300 mg } \\
\text { aqueous extract of } M \text {. oleifera leaves/kg body } \\
\text { weight. }\end{array}$ & [49] \\
\hline
\end{tabular}


Table 2. Cont.

\begin{tabular}{|c|c|c|}
\hline Physiological and Metabolic Effects & Population/Treatment Time/Applied Dose & Reference \\
\hline $\begin{array}{l}\text { Reduction in blood glucose and HbA1c levels and } \\
\text { an elevation in serum insulin and hepatic glycogen } \\
\text { levels. }\end{array}$ & $\begin{array}{l}\text { Wistar rats } / 60 \text { days } / 70 \% \text { M. oleifera leaf extract } \\
\qquad(100,250 \text { and } 500 \mathrm{mg} / \mathrm{kg} \text { b.wt./day) }\end{array}$ & {$[50]$} \\
\hline $\begin{array}{l}\text { Regulation of weight gain and inflammation } \\
\text { associated with high-fat-induced-obesity through } \\
\text { gut bacteria modulation. }\end{array}$ & $\begin{array}{c}45 \text { Swiss albino mice } / 3 \text { months } /(200 \mathrm{mg} / \mathrm{Kg} \\
\text { M. oleifera leaf extract }\end{array}$ & [51] \\
\hline
\end{tabular}

Therefore, our research group intends to discuss the effects of BFC in other nutritional disorders as well as the beneficial effects of $M$. oleifera in the previously mentioned clinical conditions. In addition, we hypothesized that BFC supplementation with M. oleifera could present a synergistic effect and play a potential benefit in nutritional disorders.

In this narrative review, we used eligibility criteria based on studies on "functional foods", (oat, flaxseed, soya and M. oleifera), "obesity", "cardiovascular disease", "diabetes mellitus type 2", "intestinal inflammatory diseases", "colorectal carcinogenesis" and "malnutrition", associated with each other by the Boolean descriptor "AND" and selected from the Health Sciences Descriptors. A bibliographic search was used for ClinicalTrials.gov, Cochrane, Europe PMC, the MEDLINE ${ }^{\circledR} /$ PubMED $^{\circledR}$ database, MDPI, Scielo, Science Direct by Elsevier, Wiley online library, Springer-Nature database, Taylor \& Francis, BMC and Hindawi, conducted, preferably, in 2010 until 2021.

Finally, this review raises the possible applicability of a BFC enriched or not with M. oleifera to act in important nutritional disorders that affect the world population.

\section{Current Status of Knowledge}

2.1. Bioactive Food Compound (BFC) and M. oleifera Nutraceuticals

A BFC is a food formulation prepared from functional foods, such as oats (Avena sativa L.), brown flaxseed (Linum usitatissimum L.) and soya (Glycine max L.) (Table 1). A patent application has been made for this BFC, which was triturated and homogenized at a ratio of 2:1:1 [19].

BFC have high nutritional quality, are rich in proteins and PUFAs and have an adequate $n-6 / n-3$ ratio and dietary fibers, such as soluble fibers, which include lignan and $\beta$-glucan [19]. As they presents high versatility, BFC have been used in individuals with metabolic alteration, demonstrating effective control of the levels of triglycerides and LDLcholesterol (low-density lipoproteins) [18]. The hypolipidemic character of BFC was shown by low atherogenicity and thrombogenicity as well as an adequate ratio between hypo- and hypercholesterolemia, PUFA: SFA and $\omega 6$ : $\omega 3$, thus, demonstrating a high quality index of the BFC lipid fraction [19]. These results demonstrated the effects of fatty acids on the cholesterol metabolism and a low risk of developing cardiovascular diseases. BFC showed a high nutritional content because it has a high protein $(24.27 \%)$ and fiber $(7.98 \%)$ content, with a total energy value ( $\left.\mathrm{kcal} 100 \mathrm{~g}^{-1}\right)$ of 335.25 [19]. In addition, this food formulation presented positive effects on the reduction of anthropometric parameters [17].

\subsection{Moringa oleifera Lamarck}

M. oleifera (syn. M. ptereygosperma Gaertn.) is a medicinal plant of the family Moringaceae, it is native to the sub-Himalayan region in the north of India, Pakistan, Africa, Asia Minor and Arabia [52,53] and has been introduced in other parts of the world [54]. It is a food plant with multiple medicinal uses. Medicinal uses of different parts of the plant, including leaves, roots, stem bark, flowers, pods and seeds, have been reported. Ethnobotanical studies confirmed M. oleifera's anti-inflammatory, antihypertensive, diuretic, antimicrobial, 
antioxidant, antidiabetic, antihyperlipidemic, antineoplastic, antipyretic, antiulcer, cardioprotective and hepatoprotective properties. In vitro and in vivo studies reinforced these pharmacological properties through the action of the secondary metabolites, including antioxidant compounds, such as ascorbic acid, flavonoids, phenolics and carotenoids, present in the plant $[55,56]$.

In addition, $M$. oleifera has a significant nutritional composition that is high in protein (about 19-29\%), dietary fiber (about 19-37\%) with about 205-350 cal/g of energy [57,58]. In addition micronutrients, such as iron, magnesium and folate, as well as vitamins of the B complex, such as B6, and vitamins A, C and E [57]. The leaves of this plant, as well as the pods and seeds, have a variety of essential phytochemicals that provide this nutritional characteristic, such as vitamins A, B, C, D and E, in addition to folic acid, pyridoxine and nicotinic acid $[55,57]$.

In summary, the functional effects of BFC and M. oleifera may represent potential action in nutraceutical strategies for the nutritional management of NCDs, IID/CRC [59-61] and malnutrition [62] Figure 1.

\subsection{Effect of Bioactive Food Compound (BFC) and M. oleifera on Non-Transmissible Chronic Diseases (NTCDs)/Metabolic Syndrome (MS)}

Among the NTCDs, obesity is a nutritional disorder, arising from the imbalance between food intake and energy output, causing excessive body fat. Studies revealed that the effects of the increased liberation of free fatty acids, inflammatory cytokines (interleukin 6 and TNF- $\alpha$ (tumoral necrosis factor alfa)), NF-KB (nuclear factor kappa B) and other byproducts of adipocytes, generated by the excess of adiposity, are due to the concentration of abdominal or central fat [63]. Obesity, now considered a worldwide crisis, is strongly associated with the risk of MS, DM2, cardiovascular diseases and cancer [64].

Therefore, dietary resources are necessary to help in the treatment of the effects and consequences of obesity. Nutritional recommendations are beneficial, such as the daily intake of soluble fibers, especially $\beta$-glucan, found in high concentrations in oat bran. The intake of fibers provides a convenient solution for the risk coming from obesity, as their solubility interferes with satiety. In addition, the constitution of $\beta$-glucan includes molecules of glucose with the bonds $\beta-(1-3)$ and $\beta-(1-4)$, which establish physicochemical properties that can act in the reduction of systemic arterial pressure, serum glucose, total cholesterol and fractions and triglycerides as well as increase the fraction of High-Density Lipoprotein (HDL-c) [65-70].

It is believed that the hypolipemiant effect of oats is related to the high viscosity, which can interfere with the uptake of biliary acids, lowering the rate of intestinal cholesterol uptake [71,72], thus, reducing the quantity of chylomicrons and, as a consequence, reducing the circulating cholesterol [73]. Furthermore, the effects of normalization of the lipidic profile of soluble fibers, such as $\beta$-glucan, are associated with their capacity to raise the level of fermentation in the colon, producing short-chain fatty acids (SCFA) [74], which indirectly reduce blood cholesterol by inhibiting the hepatic synthesis of cholesterol [75].

Oats also act on lipidic alterations arising from the elevation of insulin, as reported by El Rabey, Al-Seeni and Amer (2013) [76] and Aleixandre and Miguel (2016) [77]. In this case, there was a lower secretion of post-prandial insulin, which can result in reduced lipogenesis [78]. Insulin is responsible for the activation of the enzyme HMG-CoA reductase (3-hydroxy-3-methyl-glutaric-CoA reductase or HMGR), whose reduction can involve less synthesis of cholesterol [75] and a lower level of circulating triglycerides [73].

Another deleterious consequence of obesity is the alteration in the glycemic profile, characterizing a chronic state of hyperglycemia and a weak sensitivity to insulin. The usage of oats contributes to the maintenance of the seric glucose levels, majorly attributed to its high content of soluble fibers [79-81]. The fiber $\beta$-glucan is the one mainly responsible for anti-hyperglycemic and hypoglycemic effects. This feature is due to the capacity of $\beta$-glucan to enhance intestinal viscosity and diminish glucose uptake $[80,81]$. Furthermore, the anti-hyperglycemic and hypoglycemic properties of this soluble fiber are also attributed 
to its high content of chromium (Cr) - a mineral that acts as an insulin enhancer and, consequently, improves blood glucose levels [82].

The intake of flaxseed can also repair damage in the lipidic and glycemic profile, as it is a functional food with a high PUFA content [83]. PUFAs can contribute to reducing specific inflammatory markers and cytokines, ensuring a general improvement of the endothelial function and, consequent, cardioprotective [84,85] and anti-hyperglycemic effects [86-88].

One of the mechanisms that can explain this function is the catabolic capacity promoted by eicosapentaenoic acid (EPA) and docosahexaenoic acid (DHA) that culminates in the reduction of the lipoproteins containing the apolipoprotein B-100 (ApoB). In addition, both suppress the production of hepatic ApoB, stimulate the plasmatic depuration of triglycerides via lipoprotein lipase (LPL), raise Very Low-Density Lipoprotein (VLDL-c), reduce the synthesis of LDL-cholesterol and attenuate postprandial lipemia [89].

The lipidic characteristic of flaxseed, which is one of the best food sources of essential FAs, with a richness of phenolic and antioxidant compounds [90,91], makes this functional food an excellent daily dietary alternative. According to Kuang (2020) [92], the effect of biscuits with flaxseed meal supplement, consumed at approximately $100 \mathrm{~g}$ per day, is sufficient to obtain the metabolic benefits on body weight, BMI and TG for overweight and obese individuals.

Flaxseed has a high content of soluble fibers, above all lignan, which contributes even more to the normalization of the lipidic profile. The effect is attributed to the capacity of this fiber to modulate $7-\alpha$-hydroxylase and acyl-CoA cholesterol transferase, involved in the regulation of liver cholesterol and its conversion into biliary acids, contributing to a higher depletion of cholesterol [75].

The soluble fibers of flaxseed also allow intestinal glucose uptake to be delayed, which can attenuate the need for insulin production and, as a consequence, diminish its synthesis. Another mechanism involved in the normalization of the glycemic profile is related to the fact that lignan suppresses the gene expression of phosphoenolpyruvate carboxykinase (PEPCK), which is related to the production of glucose, through gluconeogenesis, helping in glycemic control. The effects of regularization of the glycemic profile have also been attributed to PUFAs found in brown flaxseed [88].

Considering the lipidic and glycemic consequences of obesity, soya also exerts beneficial effects. These effects are mainly attributed to the rich content of isoflavone, fibers, oligosaccharides, phytosterols, lectins and phytic acid in this legume [93-97]. The effect on weight control is more pronounced due to isoflavone, which has chemical structures similar to endogenous estrogens, resulting in the inhibition of lipogenesis and adipogenesis [96,98].

Studies also showed that soya contains bioactive peptides, which exert hypolipidemic, anti-hypertensive, antioxidant and anti-inflammatory activities, thus demonstrating their broad physiological function $[99,100]$. For example, the hypocholesterolemic peptide can act as a competitive inhibitor of the major rate-limiting enzyme in cholesterol biosynthesis3-hydroxy-3-methylglutaryl CoA reductase (HMGR). It can also increase LDL uptake in the sterol regulatory element-binding protein 2 (SREBP2) pathway [99]. The excellent applications and responses of soya on the normalization of the lipidic profile [101] have led to its approval through a health claim proving its use in reducing the risk of NTCDs [102] and, moreover, CVD [99], as can be explained by the reduction of cholesterol due the formation of insoluble complexes by soy saponins. The insoluble complexes can form mixed micelles that inhibit the resorption of bile acids in the terminal ileum [103].

The functional effects of soya are also extrapolated to the nutritional management of the glycemic profile, since soya can act in increasing sensitivity to insulin and its production by beta-pancreatic cells, in addition to inhibiting intestinal glucose uptake [93]. In this case, specifically, isoflavone has the capacity to reduce the loss of beta cells of the pancreatic islets and also presents a high antioxidant effect. This effect, especially from genistein, inhibits tyrosine kinase (PTK), the protein involved in potential alterations in insulin secretion. The isoflavones also appear to regulate postprandial glycemia by blocking the activity of the enzymes $\alpha$-amylase and $\alpha$-glycosidase, in vitro [102]. 
This takes advantage of the effects of oats, flaxseed and soya on the normalization of the lipidic and glycemic profile, through their chemical and nutritional composition, providing strategies for the nutritional management and prevention of obesity, DM2, dyslipidemia/CVD and MS [61,104-107]. These functional foods and their different bioactive properties related to NTCDs can be associated with the nutrients present in M. oleifera, which presents excellent nutritional potential and broad pharmacological properties $[20,31,108,109]$

The chemical components present in M. oleifera are fundamental for health maintenance or improvement. The plant has been applied in lipid profile adjustment [110] in an animal model and demonstrated a reduction in the total cholesterol, triglycerides and LDL-c; hence, it can be used as an effective alternative in cases of dyslipidemia [111]. The hypolipidemic effect of $M$. oleifera can be attributed to the lower biosynthesis of cholesterol through the inhibition of HMG Co-A reductase (3-hydroxy-3-methyl-glutaric-CoA reductase or HMGR), the enzyme that regulates the levels of serum and tissue cholesterol. The capacity of $M$. oleifera to improve the lipid profile can be justified due to its high content of phenolic compounds, especially flavonoids, like rutin, quercetin and kaempferol, which also contribute to reducing the intestinal absorption of cholesterol [112].

In addition, $M$. oleifera also has $\beta$-sitosterol, a phytosterol with a cholesterol-like structure, except for the substitution of an additional C-24 alkyl group and/or a C-22 double bond. Studies have demonstrated that $\beta$-sitosterol can lower serum cholesterol levels by reabsorbing endogenous cholesterol, increasing its excretion in feces as neutral steroids [113]. Other beneficial effects of phytosterols include anti-inflammatory and antipyretic properties $[114,115]$.

The functional effects of $M$. oleifera extend to the strategies for the nutritional management of DM2, taking advantage of its anti-hyperglycemic properties $[116,117]$ as well as its antioxidant potential $[118,119]$. Therefore, $M$. oleifera is widely used in human and animal studies, whose primary scope is to determine the anti-hyperglycemic effects of the plant and at the same time its antioxidant property through evaluation of the activity of enzymes, such as SOD (superoxide dismutase), CAT (catalase) and GSH (glutathione peroxidase) $[48,88,116,117,120]$

The anti-hyperglycemic effect of $M$. oleifera can be attributed to its capacity to enhance the action of insulin [50,117]. This is because the plant has considerable quantities of bioactive phytochemicals (quercetin, kaempferol, chlorogenic acid and alkaloids), which act in synergy, increasing the secretion of insulin and leading to a better use of glucose by the tissues through blockage of hepatic gluconeogenesis [50].

Considering the pronounced bioactive effects of these functional foods and M. oleifera, as well as the risk factors related to visceral fat, hypertension, low levels of HDL-c and high levels of triglycerides and glucose, configuring MS [121-123], two nutraceutical options, BFC and M. oleifera, can be recommendable.

\subsection{Alternative Therapies and/or Prophylactics for Intestinal Inflammatory Diseases (IID): Bioactive Food Compound (BFC) and M. oleifera}

In addition to NTCDs, IIDs are also characterized by inflammatory processes. The particularity of these intestinal diseases involve prolonged inflammation of the digestive tract [124]. In this case, the nutraceutical strategies of BFC and M. oleifera can also intervene in the prevention and or nutritional treatment of celiac disease, ulcerative colitis, Chron's disease, irritable bowel syndrome and even cancer, specifically CRC, one of the most worrying IIDs [60]. However, clinical trials are needed to prove this hypothesis.

The long-term dietary ingestion of oats or oat bran can confer beneficial outcomes on IIDs [125-127]. In celiac disease, for example, oats can be considered an excellent therapeutic nutritional indication, as they are nutritive and safe for a gluten-free diet [128]. However, oats should be chosen with caution, since contamination from other sources of cereals is the main problem faced by celiac patients [129].

The primary mechanism of action justifying the use of oats in the nutritional management of IIDs, including celiac disease, is regulating the bowel transit time and increasing 
the production of butyrate and/or other SCFAs by the intestinal microbiota, ensuring improved inflammatory and oxidant processes [129].

Considering that IIDs have, as their main pathologic characteristic, a severe inflammatory context, the prolonged consumption of brown flaxseed determines the increase of PUFAs, such as n-3, which is associated with a lower incidence of ulcerative colitis $[25,130]$. That is because PUFAs inhibit the synthesis of prostaglandins (PG) and leukotrienes (LT) via arachidonic FA. They also inhibit angiogenesis and adaptive immunological responses [131].

Furthermore, taking advantage of the antioxidant properties of flaxseed, there is a reduction in the severity of ulcerative colitis, with a reduction in goblet cell depletion, inflammation and scavenging ROS (reactive oxygen species) [39,132]. The reduction of the inflammatory process can be justified by the capacity of brown flaxseed to lower the TNF- $\alpha$ levels. The minimization of the oxidative process can be related to the fact that this seed acts in the inhibition of nitric oxide, through iNOS (nitric oxide inducible synthase), with negative regulation of IFN- $\gamma$ (interferon-gamma) and TNF- $\alpha$ and an increase of interleukin 17 (IL-17) [39].

Considering the reduction of inflammation and oxidative stress, both highly present in IIDs, studies revealed that the isoflavones found in soya (in the form of aglycone, which is bioavailable and rich in daidzein) have an effect on intestinal immunity, since they diminish the inflammation and colon tissue damage, thus, avoiding colitis $[133,134]$. In addition, the moderate ingestion of isoflavones in the diet can be beneficial in remission cases of ulcerative colitis, as shown in an animal model [135].

The anti-inflammatory, immunomodulator and antioxidant properties of M. oleifera are also attributed to the content of phenolic compounds, especially bisphenols and flavonoids, whose positive effects on IIDs were reported in an animal model [136]. However, there is a clinical trial evaluating the effects of $M$. oleifera leaves on the blood antioxidant status. Lipid profiles and the blood glucose level will be evaluated (NCT04314258). The antiinflammatory/antioxidant effect of M. oleifera is mediated by the transcription factor Nrf2 (nuclear factor erythroid 2-related factor 2). In addition, the plant can lower nitric acid, through iNOS, TNF- $\alpha$, myeloperoxidase (MPO) and proinflammatory interleukin, such as interleukin IL-6, all markers of inflammatory/oxidative processes [137].

The contribution of the functional foods composing BFC and M. oleifera can occur by means of chemopreventive and or chemotherapeutic properties, with anticarcinogenic and antiangiogenic effects [59]. Thus, the use of BFC and M. oleifera in the nutritional management of CRC can be justifiable due to the high content of soluble fibers, lignan and $\beta$-glucan present in flaxseed and oats $[59,81,138]$. Clinical trials are encouraged to confirm this hypothesis. These soluble fibers have high prebiotic potential, modifying the composition of the intestinal microbiota [139] and, when undergoing a fermentative process by anaerobic bacteria in the colon, they ensure the synthesis of SCFA $[139,140]$. These FAs can contribute to lowering the $\mathrm{pH}$ of the intestinal lumen for the elimination of toxins and proliferation of colon epithelial cells [139] and enhance an effect of prevention and reduction of a possible inflammatory process that would lead to the development of lesions [59].

In turn, soya is used in the prevention and nutritional treatment of CRC, justified by its high content of isoflavone, specifically genistein, daidzein and enterolactone. These substances can inhibit angiogenesis, diminish cell proliferation and increase the apoptosis of cancer cells $[27,28,141]$.

M. oleifera also has antitumoral/antiproliferative properties, since this species can act on the induction of apoptosis of tumoral cells. The mechanism of action of M. oleifera appears to be related to blocking the progression of the tumoral G2/M cycle. That effect can be attributed to the plant-rich chemical composition with various anti-cancer compounds, namely eugenol, isopropyl isothiocynate, D-allose and hexadeconoic acid ethyl ester, with long chain hydrocarbons, a sugar moiety and an aromatic ring [47]. Other 
antitumoral/antiproliferative mechanisms of $M$. oleifera include the capacity to increase oxidative stress and produce an alteration in the cell tumoral cycle, due to apoptosis [142].

\subsection{Nutraceuticals for Malnutrition: Bioactive Food Compound (BFC) and M. oleifera}

The investigation and understanding of the effects presented by the food formulation BFC and M. oleifera can also direct their application in situations where malnutrition is evident in hypercatabolic diseases, which leads to alterations of body composition and physiological functions caused by clinical conditions, which can cause a loss of appetite or hinder food ingestion $[57,62]$.

To intervene in an adjuvant way in both prevention and treatment of metabolic alterations that can lead to malnutrition, oat and its products stand out, given that numerous clinical trials demonstrate that foods and supplements with soluble fibers, particularly the $\beta$-glucan fraction, are well accepted and widely consumed [118,143,144].

Flaxseed is another functional food that is important in the nutritional management of malnutrition, as it is a source of high-quality functional protein in addition to containing lignans, gum and phenolic compounds. The protein of flaxseed can be used by patients with malnutrition associated with cancer, burns, liver failure and chronic and acute diarrhea. The components of flaxseed can be developed into various fortified functional products, owing to a high impact in the protection and treatment of various chronic diseases [145].

Foods supplemented with soya are used as dietetic formulations for the treatment of undernourished people $[29,30,146]$. That is because soya has high nutritional potential, as it is rich in proteins, carbohydrates and lipids plus minerals, such as potassium, and vitamins, such as riboflavin, choline, thiamin and pantothenic acid [147]. Soya has been incorporated in mixtures to prevent malnutrition and to improve the nutritional state of children [148]. The nutritional composition of BFC demonstrated high protein and energetic content and can be recommended for the condition of malnutrition [19].

$M$. oleifera is a nutraceutical alternative and a particularly relevant resource against malnutrition. That is because M. oleifera is rich in macro and micronutrients [57,149-151]. The plant is also considered to be a moderately adequate source of calcium, niacin (B3), protein, essential amino acids (threonine, valine, methionine, leucine, isoleucine, phenylalanine, histidine, lysine and arginine) and dietary fiber [57,108,149,152].

Due to its expressive nutritional potential, $M$. oleifera has been used in dietary formulations for the enrichment of everyday food, aiming at replacing nutrients in cases of malnutrition and anemia $[149,153]$. Given the phytochemical composition and nutritional value of $M$. oleifera demonstrated in vitro and in vivo, the use of this medicinal plant can positively impact the nutritional status in humans $[16,154]$. A clinical study showed the efficiency of $M$. oleifera leaf powder in improving the nutritional status of people living with human immunodeficiency virus (PLHIV) [155]. Another study showed the supplementation of M. oleifera leaf powder, administered in children with malnutrition, demonstrating the effectiveness in improving nutritional recovery [151]. On the other hand, the consumption of $14 \mathrm{~g}$ of $M$. oleifera did not improve the nutritional status and body composition of malnourished individuals [108,155-157]. Therefore, further clinical studies are needed to indicate $M$. oleifera for malnutrition.

Hence, the impact of incorporation or supplementation of oats, brown flaxseed, soya and M. oleifera is a critical dietary strategy in controlling malnutrition.

\section{Functional Dietary Modulation of the Intestinal Microbiota from the Nutraceuticals Bioactive Food Compound (BFC) and M. oleifera}

The intestinal microbiota is an essential component in the human body ecosystem and possibly a health modulator. The intestinal and general homeostasis of the organism is directly linked to the integrity of the intestinal mucosal barrier, thus, avoiding bacterial translocation. This can impede tissue lesions, infection by pathogens and the development of diseases [158].

Various studies revealed that functional alterations and changes in the composition of the gut microbiome are associated with NTCDs and IID, such as obesity $[159,160]$, diabetes 
mellitus [161-164], cardiometabolic disease [165], irritable bowel syndrome [166-168], CRC $[169,170]$ and malnutrition [171].

Thus, it has been pointed out that, for modulation of the microbiota, it is necessary to consider geographic, environmental, genetic and dietetic factors, in addition to the standardization of the analytical procedures. For functional characterization, it is also necessary to update the catalogues of human intestinal micro-organisms [172,173].

Regarding dietary factors, food habits can be improved by adding nutraceuticals containing soluble fibers [174], PUFAs [175], isoflavones [43] and medicinal plants. These induce functional changes and alter the composition of the intestinal microbiota [176], thus, highlighting the possibility of using nutraceutical BFC and M. oleifera.

Global dietary recommendations emphasize the intake of oats, due to the physicochemical properties and physiological responses in promoting health. The efficiency of the grain is best when associated with a hypolipidic diet, with a low content of saturated fatty acids, thus, contributing to reducing the risk of NTCDs [174]. The consumption of oats contributes to the health of the bacterial community of the distal colon, by increasing the viscosity in the gastrointestinal tract, through $\beta$-glucan and resistant starch, one of the main determinants of favorable metabolic effects [177]. There is evidence suggesting that oats raise the production of SCFA in the large intestine, triggering the homeostasis of its microbiota $[65,178]$.

The soluble fiber of oats influences an increase in the relative abundance of potentially beneficial bacteria, such as bifidobacteria and lactobacilli. It, thus, contributes in the modulation of the ecological processes that regulate the structure and function of the community of intestinal microbiome toward a profile of health promotion $[179,180]$.

The modulation of the intestinal microbiota can also occur by using flaxseed, which is rich in multiple bioactive compounds, especially lignans [181,182], PUFAs and secoisolariciresinol diglucoside (SDG), with anti-inflammatory properties [183]. Lignans, which are non-steroidal phytoestrogens, are metabolized by intestinal bacteria to access the systemic circulation in humans [184]. The antioxidant and anti-inflammatory power of flaxseed is provided by SDG, especially when ground.

SDG liberates secoisolariciresinol (SECO), which produces dihydroxyalododiol by demethylation by the microbiota and, by dihydroxylation, results in enterodiol and dehydrogenation produces enterolactone $[182,185,186]$. All these metabolic processes occur by the bio transforming action of intestinal bacteria, such as Ruminococcus bromii and $R$. lactaris [187,188], Lactobacillus casei and L. acidophilus, acting for the digestion of the whole flaxseed, to increase the bioaccessibility of the enterodiol [189]. The supplementation of flaxseed in the diet can alter the colon bacteria, with a significant increase of Prevotella spp. and decrease of Akkermansia muciniphila [42]. Further studies are necessary to better understand the mechanisms of action of dietary flaxseed in the intestinal microbiome in healthy or ill people.

Soya also has effects on the population and composition of the intestinal microbiota. The components of soya, such as isoflavones (daidzein, genistein and glycitein), can increase levels of bifidobacteria and lactobacilli and alter the relationship between Firmicutes and Bacteroidetes, thereby, diminishing the risk of diseases, leading to beneficial effects on human health [43]. Foods based on soya can serve as sources of nutrients and energy that support the growth and maintenance of intestinal bacteria [190,191]. A study on the supplementation of $20 \%$ of soy protein showed an alteration in the bacterial composition of Firmicutes, with the increase and decrease in abundance of Enterococcus and of the levels of Ruminococcus and Lactobacillus, respectively [192].

The oligosaccharides and fibers of soya have prebiotic properties and can reach the colon intact without being digested $[193,194]$. Soya fibers are the main byproduct of the fermentation of non-starch polysaccharides by the anaerobic microbiota in the intestine; they alter the level of SCFAs, such as butyrate $[195,196]$. There is evidence that the oligosaccharides and fibers can contribute to favorable effects on the intestinal microbiota [43]. They also help to increase Bacteroides, Flavonifractor, Barnesiella, Oscillibactor 
and Alistipes and cause a significative drop in the abundance of Ruminococcus, Lactococcus, Akkermansia, Hydrogenoanaerobacterium and Parabacteroides [197].

M. oleifera contributes to restoring the number of lactobacilli and bifidobacteria in the cecal portion, thereby, modulating the intestinal microbiota. The phenolic compounds demonstrated promotion of the growth of probiotics, such as Lactobacillus, and interfering with the growth inhibition of pathogenic bacteria, such as Escherichia coli [51].

Finally, there is a wide clinical indication for functional foods (oats, flaxseed and soy) and M. oleifera in nutritional disorders. Therefore, nutritional interventions, such as BFC and M. oleifera, may constitute viable alternatives in the management of chronic non-communicable diseases, inflammatory bowel diseases, malnutrition and modulation of the intestinal microbiota (Figure 2).

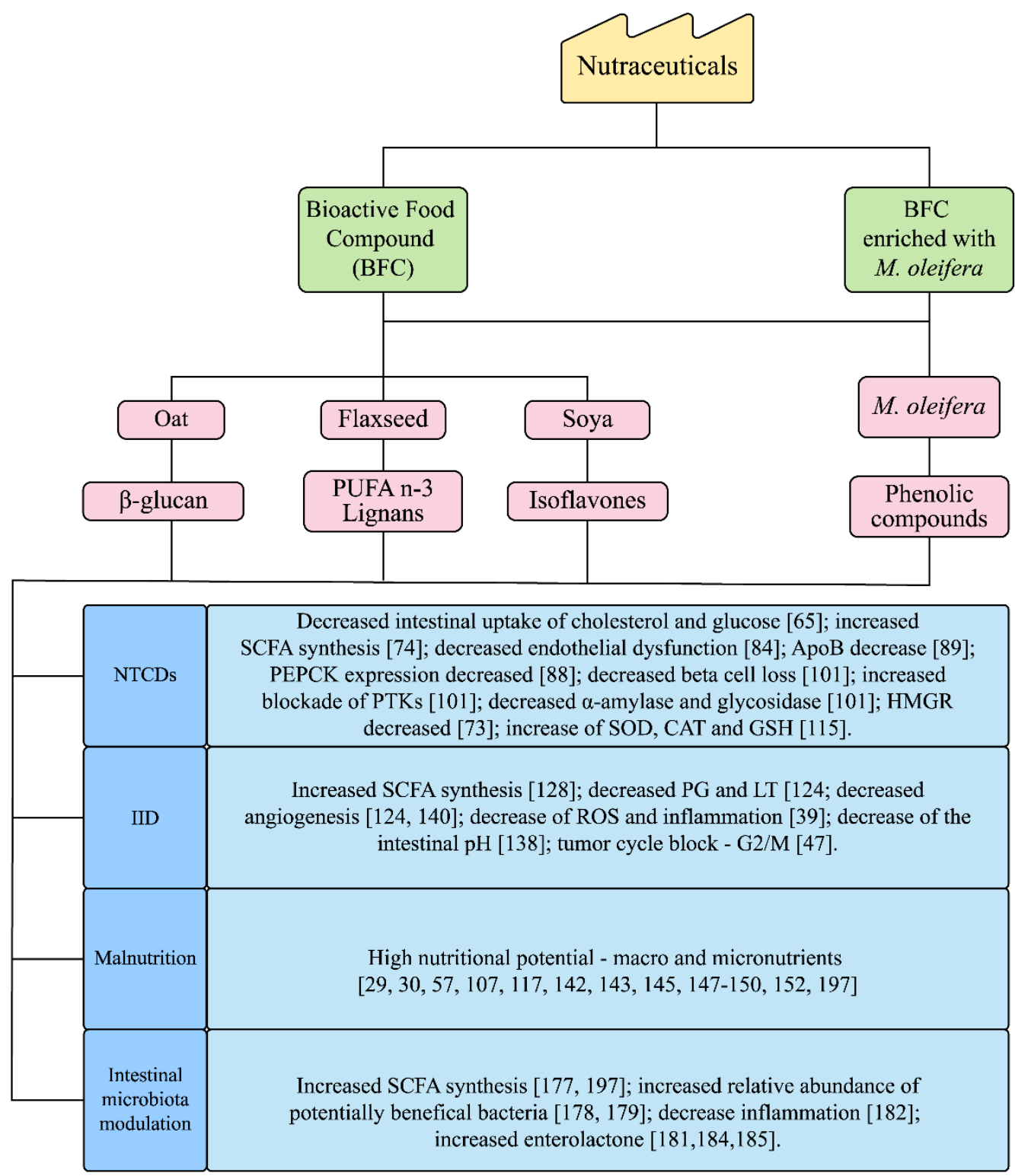

Figure 2. BFC and M. oleifera physiological and metabolic effects proposed. Short-chain fatty acids (SCFA); Apolipoprotein B (ApoB); Phosphoenolpyruvate carboxykinase (PEPCK); Tyrosine kinase (PTKs); 3- hydroxy-3-methyl-glutaric-CoA reductase (HMGR); Superoxide dismutase (SOD); Catalase (CAT); Glutathione peroxidase (GSH); Prostaglandins (PG); Leukotrienes (LT); and Reactive oxygen species (ROS). 


\section{Concluding Remarks}

BFC contains soluble fibers, polyunsaturated fatty acids, isoflavones, antioxidants, has a high nutritional value and has an impact on reducing obesity indicators in addition to adjusting the lipid profile. The BFC composition may also be signaling immunomodulatory effects on the intestinal microbiota, with preventive and therapeutic action for colorectal cancer. Based on the in vivo and in vitro results, the effects described above can be attributed to M. oleifera, as well as in blood glucose control, as it is considered an antidiabetogenic agent.

Considering the traditional consumption of preparations with $M$. oleifera, it is possible to favor their association with other formulations, such as BFC. Moreover, these nutraceuticals can be easily accepted and can be used in sweet preparations (fruit and/or vegetable juices, fruit and/or vegetable vitamins, porridges, yogurt, cream, mousses or fruit salads, cakes and cookies) or savory (vegetable purees, soups, broths and various sauces), cooked or not. These formulations can be low-cost and easy-to-use. However, it is suggested that the association of bioactive food substances in dietary formulations can facilitate adherence to consumption and, thus, contribute to the planning of future nutritional interventions for the prevention and adjuvant treatment of the clinical conditions presented in this study and can be extended to the general population.

Therefore, our review study showed the possible applicability of BFC and M. oleifera in nutritional disorders. Evidence suggests that the high nutritional values and the presence of phytochemicals in M. oleifera leaves can potentialize the beneficial effects of BFC. Thus, we propose BFC enriched with $M$. oleifera in the management of chronic non-communicable diseases, inflammatory bowel diseases, malnutrition and modulation of the intestinal microbiota. However, an investigation through clinical studies is needed to prove its applicability to BFC as well as BFC enriched with M. oleifera for these nutritional disorders.

\section{Patents}

Patent application: Instituto Nacional da Propriedade Industrial, Brazil (number BR 10 2013 018,002 5 on 6 June 2013). The BFC was launched by Ministério do Desenvolvimento e Comércio Exterior, Brazil, August 2015.

Author Contributions: Conceptualization, visualization writing—original draft, writing—review and editing: R.d.S.F. and L.A.B.M.M.; writing-review and editing: C.d.S., P.A.H., R.M., O.L.F., A.K.M.d.O., V.A.d.N., A.P. and C.M.E.C.; illustration: C.d.S. and L.A.B.M.M. and conceptualization, visualization writing — original draft, writing, review editing, supervision: R.d.C.A.G. All authors have read and agreed to the published version of the manuscript.

Funding: This study was financed in part by the Coordenação de Aperfeiçoamento de Pessoal de Nível Superior, Brazil (CAPES)—Finance Code 001.

Institutional Review Board Statement: Not applicable.

Informed Consent Statement: Not applicable.

Acknowledgments: We thank the Graduate Program in Health and Development in the Central-West Region of Brazil, Federal University of Mato Grosso do Sul-UFMS and Coordenação de Aperfeiçoamento de Pessoal de Nível Superior, Brazil (CAPES); Graduate Program in Health and Development in the Central-West Region of Brazil, Federal University of Mato Grosso do Sul-UFMS, S-Inova Biotech. Graduate Program in Biotechnology, Catholic University Dom Bosco-UCDB. Graduate Program in Environment and Regional Development, University Anhanguera Uniderp. Graduate Program in Genomic Sciences and Biotechnology, Catholic University of Brazilia, Center of Proteomic and Biochemical Analysis. Institute of Biosciences, Federal University of Mato Grosso do Sul-UFMS. National Council for Scientific and Technological Development (CNPq) and Foundation for Support to the Development of Teaching, Science and Technology of the State of Mato Grosso do Sul (FUNDECT) for support.

Conflicts of Interest: The authors declare no conflict of interest. 


\section{References}

1. Kalra, E.K. Nutraceutical definition and introduction. AAPS Pharm. Sci. 2003, 5, E25. [CrossRef]

2. Adefegha, S.A. Functional foods and nutraceuticals as dietary intervention in chronic diseases; novel perspectives for health promotion and disease prevention. J. Diet. Suppl. 2018, 15, 977-1009. [CrossRef]

3. Zhang, Y.J.; Gan, R.Y.; Li, S.; Zhou, Y.; Li, A.N.; Xu, D.P.; Li, H.B. Antioxidant phytochemicals for the prevention and treatment of chronic diseases. Molecules 2015, 20, 21138-21156. [CrossRef]

4. Berberich, A.J.; Hegele, R.A. Nutraceuticals in 2017: Nutraceuticals endocrine disorders. Nat. Rev. Endocrinol. 2018, 14, 68-70. [CrossRef]

5. Carnauba, R.A.; Baptistella, A.B.; Paschoal, V. Nutrição clínica funcional: Uma visão integrativa do paciente. Diagn Tratamento 2018, 23, 28-32. (In Portuguese)

6. Naves, A.; Paschoal, V. Nutrição Clínica Funcional: Pensando por meio do Sistema ATMS. In Nutrição Clínica Funcional—dos Princípios à Prática Clínica, 2nd ed.; Paschoal, V., Naves, A., Fonseca, A.B.B.L., Eds.; Editora VP: São Paulo, Brazil, $2014 ;$ pp. 11-14. (In Portuguese)

7. Souza, N.; Baptistella, A.B.; Paschoal, V.; Naves, A.; Massunaga, N.; Carnauba, R.; Hubscher, G. Nutrição funcional: Princípios e aplicação na prática clínica. Acta Port. Nutr. 2016, 7, 34-39.

8. Valle, D. Genetics, individuality, and medicine in the 21st century. Am. J. Hum. Genet. 2004, 74, 374-381. [CrossRef] [PubMed]

9. Agudo, A.; Cabrera, L.; Amiano, P.; Ardanaz, E.; Barricarte, A.; Berenguer, T.; Chirlaque, M.D.; Dorronsoro, M.; Jakszyn, P.; Larranaga, N. Fruit and vegetable intakes, dietary antioxidant nutrients, and total mortality in Spanish adults: Findings from the Spanish cohort of the European Prospective investigation into cancer and nutrition (EPIC-Spain). Am. J. Clin. Nutr. 2007, 85, 1634-1642. [CrossRef]

10. Andlauer, W.; Fürst, P. Nutraceuticals: A piece of history, present status and outlook. Food Res. Int. 2002, 35, 171-176. [CrossRef]

11. Hugenholtz, J.; Smid, E.J. Nutraceutical production with food-grade microorganisms. Curr. Opin. Biotechnol. 2002, 13, 497-507. [CrossRef]

12. Roberfroid, M. Functional food concept and its application to prebiotics. Dig. Liver Dis. 2002, 34, S105-S110. [CrossRef]

13. Walzem, R.L. Functional foods and health strategies. Trends Food Sci. Technol. 2004, 15, 33. [CrossRef]

14. Hayes, M.; Tiwari, B.K. Bioactive carbohydrates and peptides in foods: An overview of sources, downstream processing steps and associated bioactivities. Int. J. Mol. Sci. 2015, 16, 22485-22508. [CrossRef] [PubMed]

15. Pandey, N.; Meena, R.P.; Rai, S.K.; Pandey-Rai, S. Medicinal plants derived nutraceuticals: A re-emerging health aid. Int. J. Pharma Bio Sci. 2011, 2, 420-441.

16. Leone, A.; Spada, A.; Battezzati, A.; Schiraldi, A.; Aristil, J.; Bertoli, S. Moringa oleifera seeds and oil: Characteristics and uses for human health. Int. J. Mol. Sci. 2016, 17, 2141. [CrossRef] [PubMed]

17. Ferreira, R.d.S.; Guimarães, R.d.C.A.; Pontes, E.R.J.C.; Mendonça, L.A.B.M.; Freitas, K.d.C.; Hiane, P.A. Effectiveness of a bioactive food compound in anthropometric measures of individuals with HIV/AIDS: A nonrandomized trial. PLoS ONE 2018, 13, e0191259. [CrossRef]

18. Ferreira, R.d.S.; Guimarães, R.d.C.A.; Pontes, E.R.J.C.; Nascimento, V.A.; Hiane, P.A. The effectiveness of a bioactive food compound in the lipid control of individuals with HIV/AIDS. Nutrients 2016, 8, 598. [CrossRef] [PubMed]

19. Ferreira, R.d.S.; Hiane, P.A.; Guimarães, R.d.C.A.; Ramos, M.I.L.; Demarque, D.P.; Meira, J.E.C.d. Physicochemical, microbiological and sensory evaluation of a bioactive food blend. Food Sci. Technol. 2014, 34, 609-615. [CrossRef]

20. Leone, A.; Bertoli, S.; Di Lello, S.; Bassoli, A.; Ravasenghi, S.; Borgonovo, G.; Forlani, F.; Battezzati, A. Effect of Moringa oleifera leaf powder on postprandial blood glucose response: In vivo study on Saharawi people living in refugee camps. Nutrients 2018, 10, 1494. [CrossRef]

21. Cicero, A.F.G.; Fogacci, F.; Veronesi, M.; Strocchi, E.; Grandi, E.; Rizzoli, E.; Poli, A.; Marangoni, F.; Borghi, C. A Randomized Placebo-Controlled Clinical Trial to Evaluate the Medium-Term Effects of Oat Fibers on Human Health: The Beta-Glucan Effects on Lipid Profile, Glycemia and inTestinal Health (BELT) Study. Nutrients 2020, 12, 686. [CrossRef]

22. Whitehead, A.; Beck, E.J.; Tosh, S.; Wolever, T.M.S. Cholesterol-lowering effects of oat $\beta$-glucan: A meta-analysis of randomized controlled trials. Am. J. Clin. Nutr. 2014, 100, 1413-1421. [CrossRef] [PubMed]

23. García-Montalvo, I.A.; Méndez Díaz, S.Y.; Aguirre Guzmán, N.; Sánchez Medina, M.A.; Matías Pérez, D.; Pérez Campos, E. Increasing consumption of dietary fiber complementary to the treatment of metabolic syndrome. Nutr. Hosp. 2018, 35, 582-587. [CrossRef]

24. Hendrixson, D.T.; Godbout, C.; Los, A.; Callaghan-Gillespie, M.; Mui, M.; Wegner, D.; Bryant, T.; Koroma, A.; Manary, M.J. Treatment of severe acute malnutrition with oat or standard ready-to-use therapeutic food: A triple-blind, randomised controlled clinical trial. Gut 2020, 69, 2143-2149. [CrossRef]

25. Morshedzadeh, N.; Shahrokh, S.; Chaleshi, V.; Karimi, S.; Mirmiran, P.; Zali, M.R. The effects of flaxseed supplementation on gene expression and inflammation in ulcerative colitis patients: An open-labelled randomised controlled trial. Int. J. Clin. Pract. 2021, 75, e14035. [CrossRef]

26. Akrami, A.; Nikaein, F.; Babajafari, S.; Faghih, S.; Yarmohammadi, H. Comparison of the effects of flaxseed oil and sunflower seed oil consumption on serum glucose, lipid profile, blood pressure, and lipid peroxidation in patients with metabolic syndrome. J. Clin. Lipidol. 2018, 12, 70-77. [CrossRef] 
27. Pintova, S.; Dharmupari, S.; Moshier, E.; Zubizarreta, N.; Ang, C.; Holcombe, R.F. Genistein combined with FOLFOX or FOLFOXBevacizumab for the treatment of metastatic colorectal cancer: Phase I/II pilot study. Cancer Chemother. Pharmacol. 2019, 84, 591-598. [CrossRef]

28. Shin, A.; Lee, J.; Lee, J.; Park, M.S.; Park, J.W.; Park, S.C.; Oh, J.H.; Kim, J. Isoflavone and soyfood intake and colorectal cancer risk: A case-control study in Korea. PLoS ONE 2015, 10, e0143228. [CrossRef]

29. Iuel-Brockdorf, A.-S.; Draebel, T.A.; Ritz, C.; Fabiansen, C.; Cichon, B.; Christensen, V.B.; Yameogo, C.; Oummani, R.; Briend, A.; Michaelsen, K.F. Evaluation of the acceptability of improved supplementary foods for the treatment of moderate acute malnutrition in Burkina Faso using a mixed method approach. Appetite 2016, 99, 34-45. [CrossRef] [PubMed]

30. Ji, G.; Qi, R.; Wang, H.; Feng, C.; Leng, J. A “planting and eating soybean" project for people living with HIV/AIDS in rural Anhui-A pilot study in China. AIDS Care 2010, 22, 126-132. [CrossRef]

31. Chan Sun, M.; Ruhomally, Z.B.; Boojhawon, R.; Neergheen-Bhujun, V.S. Consumption of Moringa oleifera Lam leaves lowers postprandial blood pressure. J. Am. College Nutr. 2020, 39, 54-62. [CrossRef] [PubMed]

32. Taweerutchana, R.; Lumlerdkij, N.; Vannasaeng, S.; Akarasereenont, P.; Sriwijitkamol, A. Effect of Moringa oleifera leaf capsules on glycemic control in therapy-naive type 2 diabetes patients: A randomized placebo controlled study. Evid. Based Complement. Altern. Med. 2017, 2017, 6581390. [CrossRef]

33. Anthanont, P.; Lumlerdkij, N.; Akarasereenont, P.; Vannasaeng, S.; Sriwijitkamol, A. Moringa oleifera leaf increases insulin secretion after single dose administration: A preliminary study in healthy subjects. J. Med Assoc. Thail. 2016, 99, 308-313.

34. El-Meidany, W.M.R.; Tayel, D.I.; El-Nawawy, A.A. Effect of Moringa oleifera water extract on Pyrexia: A case study. Can. J. Clin. Nutr. 2018, 6, 57-61. [CrossRef]

35. Shija, A.E.; Rumisha, S.F. Effect of Moringa oleifera leaf powder supplementation on reducing anemia in children below two years in Kisarawe District, Tanzania. Food Sci. Nutr. 2019, 7, 2584-2594. [CrossRef] [PubMed]

36. Dominguez-Rodriguez, M.; Valenzuela-Rubio, N.G.; Ochoa-Acosta, D.A.; Fierros-Valdez, J.A.; Castro-Sanchez, F.H.; VergaraJimenez, M. The effect of Moringa oleifera leaves in anthropometric and biochemical parameters in obese type 2 diabetes mellitus subjects. FASEB J. 2016, 30, 1176.21. [CrossRef]

37. Zhou, X.; Lin, W.; Tong, L.; Liu, X.; Zhong, K.; Liu, L.; Wang, L.; Zhou, S. Hypolipidaemic effects of oat flakes and $\beta$-glucans derived from four Chinese naked oat (Avena nuda) cultivars in Wistar-Lewis rats. J. Sci. Food Agric. 2016, 96, 644-649. [CrossRef] [PubMed]

38. Wilczak, J.; Błaszczyk, K.; Kamola, D.; Gajewska, M.; Harasym, J.P.; Jałosińska, M.; Gudej, S.; Suchecka, D.; Oczkowski, M.; Gromadzka-Ostrowska, J. The effect of low or high molecular weight oat beta-glucans on the inflammatory and oxidative stress status in the colon of rats with LPS-induced enteritis. Food Funct. 2015, 6, 590-603. [CrossRef]

39. Palla, A.H.; Iqbal, N.T.; Minhas, K.; Gilani, A.H. Flaxseed extract exhibits mucosal protective effect in acetic acid induced colitis in mice by modulating cytokines, antioxidant and antiinflammatory mechanisms. Int. Immunopharmacol. 2016, 38, 153-166. [CrossRef]

40. Ghule, A.E.; Jadhav, S.S.; Bodhankar, S.L. Effect of ethanolic extract of seeds of Linum usitatissimum (Linn.) in hyperglycaemia associated ROS production in PBMNCs and pancreatic tissue of alloxan induced diabetic rats. Asian Pac. J. Trop. Dis. 2012, 2, 405-410. [CrossRef]

41. Dusane, M.B.; Joshi, B.N. Beneficial effect of flax seeds in streptozotocin (STZ) induced diabetic mice: Isolation of active fraction having islet regenerative and glucosidase inhibitory properties. Can. J. Physiol. Pharmacol. 2013, 91, 325-331. [CrossRef]

42. Power, K.A.; Lepp, D.; Zarepoor, L.; Monk, J.M.; Wu, W.; Tsao, R.; Liu, R. Dietary flaxseed modulates the colonic microenvironment in healthy C57Bl/6 male mice which may alter susceptibility to gut-associated diseases. J. Nutr. Biochem. 2016, 28, 61-69. [CrossRef]

43. Huang, H.; Krishnan, H.B.; Pham, Q.; Yu, L.L.; Wang, T.T.Y. Soy and gut microbiota: Interaction and implication for human health. J. Agric. Food Chem. 2016, 64, 8695-8709. [CrossRef]

44. Zhao, Y.; Wang, P.; Sang, S. Dietary genistein inhibits methylglyoxal-induced advanced glycation end product formation in mice fed a high-fat diet. J. Nutr. 2019, 149, 776-787. [CrossRef] [PubMed]

45. Lu, J.; Zhang, X.; Liu, Y.; Cao, H.; Han, Q.; Xie, B.; Fan, L.; Li, X.; Hu, J.; Yang, G. Effect of fermented corn-soybean meal on serum immunity, the expression of genes related to gut immunity, gut microbiota, and bacterial metabolites in grower-finisher pigs. Front. Microbiol. 2019, 10, 2620. [CrossRef] [PubMed]

46. Chumark, P.; Khunawat, P.; Sanvarinda, Y.; Phornchirasilp, S.; Morales, N.P.; Phivthong-Ngam, L.; Ratanachamnong, P.; Srisawat, S.; Klai-upsorn, S.P. The in vitro and ex vivo antioxidant properties, hypolipidaemic and antiatherosclerotic activities of water extract of Moringa oleifera Lam. leaves. J. Ethnopharmacol. 2008, 116, 439-446. [CrossRef] [PubMed]

47. Al-Asmari, A.K.; Albalawi, S.M.; Athar, M.T.; Khan, A.Q.; Al-Shahrani, H.; Islam, M. Moringa oleifera as an anti-cancer agent against breast and colorectal cancer cell lines. PLoS ONE 2015, 10, e0135814. [CrossRef]

48. Oboh, G.; Oyeleye, S.I.; Akintemi, O.A.; Olasehinde, T.A. Moringa oleifera supplemented diet modulates nootropic-related biomolecules in the brain of STZ-induced diabetic rats treated with acarbose. Metab. Brain Dis. 2018, 33, 457-466. [CrossRef] [PubMed]

49. Mohamed, M.A.; Ahmed, M.A.; El Sayed, R.A. Molecular effects of Moringa leaf extract on insulin resistance and reproductive function in hyperinsulinemic male rats. J. Diabetes Metab. Disord. 2019, 18, 487-494. [CrossRef] [PubMed] 
50. Jangir, R.N.; Jain, G.C. Antidiabetic and antioxidant potential of hydroalcoholic extract of Moringa oleifera leaves in streptozotocininduced diabetic rats. Eur. J. Pharm. Med Res. 2016, 3, 438-450.

51. Elabd, E.M.Y.; Morsy, S.M.; Elmalt, H.A. Investigating of Moringa oleifera role on Gut microbiota composition and inflammation associated with obesity following high fat diet feeding. Open Access Maced. J. Med Sci. 2018, 6, 1359. [CrossRef]

52. Mughal, M.H.; Ali, G.; Srivastava, P.S.; Iqbal, M. Improvement of drumstick (Moringa pterygosperma Gaertn.)—A unique source of food and medicine through tissue culture. Hamdard. Med. 1999, 42, 37-42.

53. Somali, M.A.; Bajneid, M.A.; Al-Fhaimani, S.S. Chemical composition and characteristics of Moringa peregrina seeds and seeds oil. J. Am. Oil Chem. Soc. 1984, 61, 85-86. [CrossRef]

54. Morton, J.F. The horseradish tree, Moringa pterygosperma (Moringaceae)-A boon to arid lands? Econ. Bot. 1991, 45, 318-333. [CrossRef]

55. Stohs, S.J.; Hartman, M.J. Review of the safety and efficacy of Moringa oleifera. Phytother. Res. 2015, 29, 796-804. [CrossRef] [PubMed]

56. Abdull Razis, A.F.; Ibrahim, M.D.; Kntayya, S.B. Health benefits of Moringa oleifera. Asian Pac. J. Cancer Prev. 2014, 15, 8571-8576. [CrossRef]

57. Gopalakrishnan, L.; Doriya, K.; Kumar, D.S. Moringa oleifera: A review on nutritive importance and its medicinal application. Food Sci. Hum. Wellness 2016, 5, 49-56. [CrossRef]

58. Promkum, C.; Kupradinun, P.; Tuntipopipat, S.; Butryee, C. Nutritive evaluation and effect of Moringa oleifera pod on clastogenic potential in the mouse. Asian Pac. J. Cancer Prev. APJCP 2010, 11, 627-632. [PubMed]

59. Mendonça, L.A.B.M.; dos Santos Ferreira, R.; de Cássia Avellaneda Guimarães, R.; de Castro, A.P.; Franco, O.L.; Matias, R.; Carvalho, C.M.E. The complex puzzle of interactions among functional food, gut microbiota, and colorectal cancer. Front. Oncol. 2018, 8, 325. [CrossRef]

60. Stidham, R.W.; Higgins, P.D.R. Translational research in colorectal cancer: Colorectal cancer in inflammatory bowel disease. Clin. Colon Rectal Surg. 2018, 31, 168. [PubMed]

61. Velikonja, A.; Lipoglavšek, L.; Zorec, M.; Avguštin, G. Alterations in gut microbiota composition and metabolic parameters after dietary intervention with barley beta glucans in patients with high risk for metabolic syndrome development. Anaerobe 2019, 55, 67-77. [CrossRef]

62. WHO. World Health Organization Malnutrition. Available online: https://www.who.int/news-room/fact-sheets/detail/ malnutrition (accessed on 15 September 2020).

63. Paley, C.A.; Johnson, M.I. Abdominal obesity and metabolic syndrome: Exercise as medicine? BMC Sports Sci. Med. Rehabil. 2018, 10, 1-8. [CrossRef] [PubMed]

64. WHO. World Health Organization. Obesidad y Sobrepeso. Available online: https://www.who.int/es/news-room/fact-sheets/ detail/obesity-and-overweight (accessed on 20 July 2020). (In Spanish).

65. Gunness, P.; Gidley, M.J. Mechanisms underlying the cholesterol-lowering properties of soluble dietary fibre polysaccharides. Food Funct. 2010, 1, 149-155. [CrossRef] [PubMed]

66. Ho, H.V.T.; Sievenpiper, J.L.; Zurbau, A.; Mejia, S.B.; Jovanovski, E.; Au-Yeung, F.; Jenkins, A.L.; Vuksan, V. The effect of oat $\beta$-glucan on LDL-cholesterol, non-HDL-cholesterol and apoB for CVD risk reduction: A systematic review and meta-analysis of randomised-controlled trials. Br. J. Nutr. 2016, 116, 1369-1382. [CrossRef] [PubMed]

67. Jane, M.; McKay, J.; Pal, S. Effects of daily consumption of psyllium, oat bran and polyGlycopleX on obesity-related disease risk factors: A critical review. Nutrition 2019, 57, 84-91. [CrossRef]

68. Marset, J.B.; Casas-Agustench, P.; Sánchez, N.B.; Salas-Salvadó, J. Knowledge, interest, predisposition and evaluation of functional foods in Spanish dietitians-nutritionists and experts in human nutrition and dietetics. Nutr. Hosp. 2012, 27, 632-644.

69. Othman, R.A.; Moghadasian, M.H.; Jones, P.J.H. Cholesterol-lowering effects of oat $\beta$-glucan. Nutr. Rev. 2011, 69, 299-309. [CrossRef]

70. Williams, P.G. The benefits of breakfast cereal consumption: A systematic review of the evidence base. Adv. Nutr. 2014, 5, 636S-673S. [CrossRef]

71. Riccioni, G.; Sblendorio, V.; Gemello, E.; Di Bello, B.; Scotti, L.; Cusenza, S.; D'Orazio, N. Dietary fibers and cardiometabolic diseases. Int. J. Mol. Sci. 2012, 13, 1524-1540. [CrossRef]

72. Sima, P.; VannuccI, L.; VetvicKa, V. $\beta$-glucans and cholesterol. Int. J. Mol. Med. 2018, 41, 1799-1808.

73. Dias, C.B.; Moughan, P.J.; Wood, L.G.; Singh, H.; Garg, M.L. Postprandial lipemia: Factoring in lipemic response for ranking foods for their healthiness. Lipids Health Dis. 2017, 16, 1-11. [CrossRef] [PubMed]

74. Gulati, S.; Misra, A.; Pandey, R.M. Effects of $3 \mathrm{~g}$ of soluble fiber from oats on lipid levels of Asian Indians-a randomized controlled, parallel arm study. Lipids Health Dis. 2017, 16, 1-8. [CrossRef] [PubMed]

75. Barroso, S.G.; das Dores, S.M.C.; Azeredo, V.B. Effects of functional foods consumption on the lipid profile and nutritional status of elderly. Int. J. Cardiovasc. Sci. 2015, 28, 400-408.

76. El Rabey, H.A.; Al-Seeni, M.N.; Amer, H.M. Efficiency of barley bran and oat bran in ameliorating blood lipid profile and the adverse histological changes in hypercholesterolemic male rats. BioMed Res. Int. 2013, 2013, 263594. [CrossRef] [PubMed]

77. Aleixandre, A.; Miguel, M. Dietary fiber and blood pressure control. Food Funct. 2016, 7, 1864-1871. [CrossRef] [PubMed] 
78. Drozdowski, L.A.; Reimer, R.A.; Temelli, F.; Bell, R.C.; Vasanthan, T.; Thomson, A.B.R. $\beta$-Glucan extracts inhibit the in vitro intestinal uptake of long-chain fatty acids and cholesterol and down-regulate genes involved in lipogenesis and lipid transport in rats. J. Nutr. Biochem. 2010, 21, 695-701. [CrossRef]

79. Hou, Q.; Li, Y.; Li, L.; Cheng, G.; Sun, X.; Li, S.; Tian, H. The metabolic effects of oats intake in patients with type 2 diabetes: A systematic review and meta-analysis. Nutrients 2015, 7, 10369-10387. [CrossRef]

80. Li, Y.-H.; Niu, Y.-B.; Sun, Y.; Zhang, F.; Liu, C.-X.; Fan, L.; Mei, Q.-B. Role of phytochemicals in colorectal cancer prevention. World J. Gastroenterol. WJG 2015, 21, 9262. [CrossRef]

81. Shen, X.L.; Zhao, T.; Zhou, Y.; Shi, X.; Zou, Y.; Zhao, G. Effect of oat $\beta$-glucan intake on glycaemic control and insulin sensitivity of diabetic patients: A meta-analysis of randomized controlled trials. Nutrients 2016, 8, 39. [CrossRef]

82. Paschoal, V.; Naves, A.; da Fonseca, A. Nutrição Clínica Funcional: Suplementação Nutricional; VP Editora: São Paulo, Brazil, 2013.

83. Machado, A.M.; de Paula, H.; Cardoso, L.D.; Costa, N.M.B. Effects of brown and golden flaxseed on the lipid profile, glycemia, inflammatory biomarkers, blood pressure and body composition in overweight adolescents. Nutrition 2015, 31, 90-96. [CrossRef]

84. Haghighatsiar, N.; Askari, G.; Saraf-Bank, S.; Feizi, A.; Keshmiri, H. Effect of flaxseed powder on cardiovascular risk factor in dyslipidemic and hypertensive patients. Int. J. Prev. Med. 2019, 10, 218.

85. Khan, S. Potential role of Escherichia coli DNA mismatch repair proteins in colon cancer. Crit. Rev. Oncol. Hematol. 2015, 96, 475-482. [CrossRef]

86. Venkatachalam, S.; Ponnuswamy, T.K.; Bindu, G.; Devi, Y.; Arvind, E. Comparison of the hypoglycemic effect of flaxseed and metformin in streptozotocin induced diabetic rats. Eur. J. Pharm. Med Res. 2015, 2, 594-603.

87. Ali, A.A.; Abd Al Haleem, E.N.; Khaleel, S.A.-H.; Sallam, A.S. Protective effect of cardamonin against acetic acid-induced ulcerative colitis in rats. Pharmacol. Rep. 2017, 69, 268-275. [CrossRef]

88. Mohammadi-Sartang, M.; Sohrabi, Z.; Barati-Boldaji, R.; Raeisi-Dehkordi, H.; Mazloom, Z. Flaxseed supplementation on glucose control and insulin sensitivity: A systematic review and meta-analysis of 25 randomized, placebo-controlled trials. Nutr. Res. 2018, 76, 125-139. [CrossRef]

89. Pizzini, A.; Lunger, L.; Demetz, E.; Hilbe, R.; Weiss, G.; Ebenbichler, C.; Tancevski, I. The role of omega-3 fatty acids in reverse cholesterol transport: A review. Nutrients 2017, 9, 1099. [CrossRef] [PubMed]

90. Hasiewicz-Derkacz, K.; Kulma, A.; Czuj, T.; Prescha, A.; Żuk, M.; Grajzer, M.; Łukaszewicz, M.; Szopa, J. Natural phenolics greatly increase flax (Linum usitatissimum) oil stability. BMC Biotechnol. 2015, 15, 1-14. [CrossRef]

91. Tavarini, S.; Castagna, A.; Conte, G.; Foschi, L.; Sanmartin, C.; Incrocci, L.; Ranieri, A.; Serra, A.; Angelini, L.G. Evaluation of chemical composition of two linseed varieties as sources of health-beneficial substances. Molecules 2019, 24, 3729. [CrossRef] [PubMed]

92. Kuang, X.; Kong, Y.; Hu, X.; Li, K.; Guo, X.; Liu, C. Defatted flaxseed flour improves weight loss and lipid profile in overweight and obese adults: A randomized controlled trial. Food Funct. 2020, 11, 8237-8247. [CrossRef]

93. Karamali, M.; Kashanian, M.; Alaeinasab, S.; Asemi, Z. The effect of dietary soy intake on weight loss, glycaemic control, lipid profiles and biomarkers of inflammation and oxidative stress in women with polycystic ovary syndrome: A randomised clinical trial. J. Hum. Nutr. Diet. 2018, 31, 533-543. [CrossRef] [PubMed]

94. Jamilian, M.; Asemi, Z. The effect of soy intake on metabolic profiles of women with gestational diabetes mellitus. J. Clin. Endocrinol. Metab. 2015, 100, 4654-4661. [CrossRef] [PubMed]

95. McGraw, N.J.; Krul, E.S.; Grunz-Borgmann, E.; Parrish, A.R. Soy-based renoprotection. World J. Nephrol. 2016, 5, 233. [CrossRef]

96. Wang, X.-L.; Chiang, T.-Y.; Roux, N.; Hao, G.; Ge, X.-J. Genetic diversity of wild banana (Musa balbisiana Colla) in China as revealed by AFLP markers. Genet. Resour. Crop Evol. 2007, 54, 1125-1132. [CrossRef]

97. Kusunoki, M.; Sato, D.; Tsutsumi, K.; Tsutsui, H.; Nakamura, T.; Oshida, Y. Black soybean extract improves lipid profiles in fenofibrate-treated type 2 diabetics with postprandial hyperlipidemia. J. Med. Food 2015, 18, 615-618. [CrossRef]

98. Akhlaghi, M.; Zare, M.; Nouripour, F. Effect of soy and soy isoflavones on obesity-related anthropometric measures: A systematic review and meta-analysis of randomized controlled clinical trials. Adv. Nutr. 2017, 8, 705-717. [CrossRef]

99. Chatterjee, C.; Gleddie, S.; Xiao, C.-W. Soybean bioactive peptides and their functional properties. Nutrients $2018,10,1211$. [CrossRef]

100. Mosallanezhad, Z.; Mahmoodi, M.; Ranjbar, S.; Hosseini, R.; Clark, C.C.T.; Carson-Chahhoud, K.; Norouzi, Z.; Abbasian, A.; Sohrabi, Z.; Jalali, M. Soy intake is associated with lowering blood pressure in adults: A systematic review and meta-analysis of randomized double-blind placebo-controlled trials. Complement Ther. Med. 2021, 59, 102692. [CrossRef]

101. Mejia, S.B.; Messina, M.; Li, S.S.; Viguiliouk, E.; Chiavaroli, L.; Khan, T.A.; Srichaikul, K.; Mirrahimi, A.; Sievenpiper, J.L.; Kris-Etherton, P. A meta-analysis of 46 studies identified by the FDA demonstrates that soy protein decreases circulating LDL and total cholesterol concentrations in adults. J. Nutr. 2019, 149, 968-981.

102. Ramdath, D.D.; Padhi, E.M.T.; Sarfaraz, S.; Renwick, S.; Duncan, A.M. Beyond the cholesterol-lowering effect of soy protein: A review of the effects of dietary soy and its constituents on risk factors for cardiovascular disease. Nutrients 2017, 9, 324. [CrossRef] [PubMed]

103. Cohn, J.S.; Kamili, A.; Wat, E.; Chung, R.W.; Tandy, S. Reduction in intestinal cholesterol absorption by various food components: Mechanisms and implications. Atheroscler. Suppl. 2010, 11, 45-48. [CrossRef] [PubMed]

104. Cao, Y.; Zou, S.; Xu, H.; Li, M.; Tong, Z.; Xu, M.; Xu, X. Hypoglycemic activity of the Baker's yeast $\beta$-glucan in obese/type 2 diabetic mice and the underlying mechanism. Mol. Nutr. Food Res. 2016, 60, 2678-2690. [CrossRef] [PubMed] 
105. Sharma, S.; Goyal, R.; Barwal, S. Domestic processing effects on physicochemical, nutritional and anti-nutritional attributes in soybean (Glycine max L. Merill). Int. Food Res. J. 2013, 20, 3203-3209.

106. Soltanian, N.; Janghorbani, M. Effect of flaxseed or psyllium vs. placebo on management of constipation, weight, glycemia, and lipids: A randomized trial in constipated patients with type 2 diabetes. Clin. Nutr. ESPEN 2019, 29, 41-48. [CrossRef] [PubMed]

107. Jamilian, M.; Tabassi, Z.; Reiner, Ž.; Panahandeh, I.; Naderi, F.; Aghadavod, E.; Amirani, E.; Taghizadeh, M.; Shafabakhsh, R.; Satari, M.; et al. The effects of $\mathrm{n}-3$ fatty acids from flaxseed oil on genetic and metabolic profiles in patients with gestational diabetes mellitus: A randomised, double-blind, placebo-controlled trial. Br. J. Nutr. 2020, 123, 792-799. [CrossRef]

108. Fernandes, Â.; Bancessi, A.; Pinela, J.; Dias, M.I.; Liberal, Â.; Calhelha, R.C.; Ćirić, A.; Soković, M.; Catarino, L.; Ferreira, I.C.F.R. Nutritional and phytochemical profiles and biological activities of Moringa oleifera Lam. edible parts from Guinea-Bissau (West Africa). Food Chem. 2021, 341, 128229. [CrossRef] [PubMed]

109. Dixit, K.; Kamath, D.V.; Alluri, K.V.; Davis, B.A. Efficacy of a novel herbal formulation for weight loss demonstrated in a 16-week randomized, double-blind, placebo-controlled clinical trial with healthy overweight adults. Diabetes Obes. Metab. 2018, 20, 2633-2641. [CrossRef]

110. Mbikay, M. Therapeutic potential of Moringa oleifera leaves in chronic hyperglycemia and dyslipidemia: A review. Front. Pharmacol. 2012, 3, 24. [CrossRef]

111. Metwally, F.M.; Rashad, H.M.; Ahmed, H.H.; Mahmoud, A.A.; Abdol Raouf, E.R.; Abdalla, A.M. Molecular mechanisms of the anti-obesity potential effect of Moringa oleifera in the experimental model. Asian Pac. J. Trop. Biomed. 2017, 7, 214-221. [CrossRef]

112. Vergara-Jimenez, M.; Almatrafi, M.M.; Fernandez, M.L. Bioactive components in Moringa oleifera leaves protect against chronic disease. Antioxidants 2017, 6, 91. [CrossRef]

113. Jain, P.G.; Patil, S.D.; Haswani, N.G.; Girase, M.V.; Surana, S.J. Hypolipidemic activity of Moringa oleifera Lam., Moringaceae, on high fat diet induced hyperlipidemia in albino rats. Rev. Bras. Farmacogn. 2010, 20, 969-973. [CrossRef]

114. Bhattacharya, A.; Tiwari, P.; Sahu, P.K.; Kumar, S. A Review of the phytochemical and pharmacological characteristics of Moringa oleifera. J. Pharm. Bioallied Sci. 2018, 10, 181-191. [CrossRef]

115. Abd Rani, N.Z.; Husain, K.; Kumolosasi, E. Moringa genus: A review of phytochemistry and pharmacology. Front. Pharmacol. 2018, 9, 108. [CrossRef]

116. Omodanisi, E.I.; Aboua, Y.G.; Oguntibeju, O.O. Assessment of the anti-hyperglycaemic, anti-inflammatory and antioxidant activities of the methanol extract of Moringa oleifera in diabetes-induced nephrotoxic male wistar rats. Molecules 2017, 22, 439. [CrossRef] [PubMed]

117. Jaiswal, D.; Rai, P.K.; Mehta, S.; Chatterji, S.; Shukla, S.; Rai, D.K.; Sharma, G.; Sharma, B.; Watal, G. Role of Moringa oleifera in regulation of diabetes-induced oxidative stress. Asian Pac. J. Trop. Med. 2013, 6, 426-432. [CrossRef]

118. Singh, R.; Devi, S.; Gollen, R. Role of free radical in atherosclerosis, diabetes and dyslipidaemia: Larger-than-life. Diabetes Metab. Res. Rev. 2015, 31, 113-126. [CrossRef] [PubMed]

119. Xu, Y.-B.; Chen, G.-L.; Guo, M.-Q. Antioxidant and anti-inflammatory activities of the crude extracts of Moringa oleifera from Kenya and their correlations with flavonoids. Antioxidants 2019, 8, 296. [CrossRef]

120. Aju, B.Y.; Rajalakshmi, R.; Mini, S. Protective role of Moringa oleifera leaf extract on cardiac antioxidant status and lipid peroxidation in streptozotocin induced diabetic rats. Heliyon 2019, 5, e02935. [CrossRef]

121. Yamashita, Y.; Nakamura, A.; Nanba, F.; Saito, S.; Toda, T. Black soybean improves vascular function and blood pressure: A randomized, placebo controlled, crossover trial in humans. Nutrients 2020, 12, 2755. [CrossRef]

122. Khan, M.I.; Anjum, F.M.; Sohaib, M.; Sameen, A. Tackling metabolic syndrome by functional foods. Rev. Endocr. Metab. Disord. 2013, 14, 287-297. [CrossRef]

123. Irfan, H.M.; Khan, N.A.K.; Asmawi, M.Z. Moringa oleifera Lam. leaf extracts reverse metabolic syndrome in Sprague Dawley rats fed high-fructose high fat diet for 60-days. Arch. Physiol. Biochem. 2020, 15, 1-7. [CrossRef]

124. Zhang, Y.-Z.; Li, Y.-Y. Inflammatory bowel disease: Pathogenesis. World J. Gastroenterol. WJG 2014, 20, 91. [CrossRef] [PubMed]

125. Ananthakrishnan, A.N.; Khalili, H.; Konijeti, G.G.; Higuchi, L.M.; De Silva, P.; Korzenik, J.R.; Fuchs, C.S.; Willett, W.C.; Richter, J.M.; Chan, A.T. A prospective study of long-term intake of dietary fiber and risk of Crohn's disease and ulcerative colitis. Gastroenterology 2013, 145, 970-977. [CrossRef]

126. Thies, F.; Masson, L.F.; Boffetta, P.; Kris-Etherton, P. Oats and bowel disease: A systematic literature review. Br. J. Nutr. 2014, 112, S31-S43. [CrossRef]

127. Aaltonen, K.; Laurikka, P.; Huhtala, H.; Mäki, M.; Kaukinen, K.; Kurppa, K. The long-term consumption of oats in celiac disease patients is safe: A large cross-sectional study. Nutrients 2017, 9, 611. [CrossRef] [PubMed]

128. Gilissen, L.J.W.J.; Van der Meer, I.M.; Smulders, M.J.M. Why oats are safe and healthy for celiac disease patients. Med. Sci. 2016, 4, 21. [CrossRef] [PubMed]

129. Comino Montilla, I.M.; Moreno Amador, M.d.L.; Sousa Martín, C. Role of oats in celiac disease. World J. Gastroenterol. 2015, 21, 11825-11831. [CrossRef]

130. Scaioli, E.; Liverani, E.; Belluzzi, A. The imbalance between n-6/n-3 polyunsaturated fatty acids and inflammatory bowel disease: A comprehensive review and future therapeutic perspectives. Int. J. Mol. Sci. 2017, 18, 2619. [CrossRef] [PubMed]

131. Wang, B.; Wu, L.; Chen, J.; Dong, L.; Chen, C.; Wen, Z.; Hu, J.; Fleming, I.; Wang, D.W. Metabolism pathways of arachidonic acids: Mechanisms and potential therapeutic targets. Signal Transduct. Target. Ther. 2021, 6, 1-30. 
132. Palla, A.H.; Gilani, A.-U.-H.; Bashir, S.; Ur Rehman, N. Multiple mechanisms of flaxseed: Effectiveness in inflammatory bowel disease. Evid. Based Complement. Altern. Med. 2020, 2020, 7974835. [CrossRef] [PubMed]

133. Luo, Q.; Cheng, D.; Huang, C.; Li, Y.; Lao, C.; Xia, Y.; Liu, W.; Gong, X.; Hu, D.; Li, B. Improvement of colonic immune function with soy isoflavones in high-fat diet-induced obese rats. Molecules 2019, 24, 1139. [CrossRef]

134. Wu, Z.-Y.; Sang, L.-X.; Chang, B. Isoflavones and inflammatory bowel disease. World J. Clin. Cases 2020, 8, 2081. [CrossRef]

135. Głąbska, D.; Guzek, D.; Grudzińska, D.; Lech, G. Influence of dietary isoflavone intake on gastrointestinal symptoms in ulcerative colitis individuals in remission. World J. Gastroenterol. 2017, 23, 5356. [CrossRef]

136. Minaiyan, M.; Asghari, G.; Taheri, D.; Saeidi, M.; Nasr-Esfahani, S. Anti-inflammatory effect of Moringa oleifera Lam. seeds on acetic acid-induced acute colitis in rats. Avicenna J. Phytomed. 2014, 4, 127-136.

137. Jaja-Chimedza, A.; Graf, B.L.; Simmler, C.; Kim, Y.; Kuhn, P.; Pauli, G.F.; Raskin, I. Biochemical characterization and antiinflammatory properties of an isothiocyanate-enriched moringa (Moringa oleifera) seed extract. PLoS ONE 2017, 12, e0182658. [CrossRef]

138. Markowiak, P.; Śliżewska, K. Effects of probiotics, prebiotics, and synbiotics on human health. Nutrients 2017, 9, 1021. [CrossRef]

139. Carreiro, D.M. O Ecossistema Intestinal na Saúde e na Doença; Ed. Metha: São Paulo, Brazil, 2016. (In Portuguese)

140. Siegel, R.L.; Miller, K.D.; Jemal, A. Cancer statistics, 2016. Cancer J. Clin. 2016, 66, 7-30. [CrossRef]

141. Ko, K.-P.; Yeo, Y.; Yoon, J.-H.; Kim, C.-S.; Tokudome, S.; Koriyama, C.; Lim, Y.-K.; Chang, S.-H.; Shin, H.-R.; Kang, D. Plasma phytoestrogens concentration and risk of colorectal cancer in two different Asian populations. Clin. Nutr. 2018, 37, 1675-1682. [CrossRef] [PubMed]

142. Cuellar-Núñez, M.L.; Loarca-Piña, G.; Berhow, M.; Gonzalez de Mejia, E. Glucosinolate-rich hydrolyzed extract from Moringa oleifera leaves decreased the production of TNF- $\alpha$ and IL- $1 \beta$ cytokines and induced ROS and apoptosis in human colon cancer cells. J. Funct. Foods 2020, 75, 104270. [CrossRef]

143. Sturtzel, B.; Dietrich, A.; Wagner, K.H.; Gisinger, C.; Elmadfa, I. The status of vitamins B6, B12, folate, and of homocysteine in geriatric home residents receiving laxatives or dietary fiber. J. Nutr. Health Aging 2010, 14, 219-223. [CrossRef] [PubMed]

144. Tsikritzi, R.; Moynihan, P.J.; Gosney, M.A.; Allen, V.J.; Methven, L. The effect of macro-and micro-nutrient fortification of biscuits on their sensory properties and on hedonic liking of older people. J. Sci. Food Agric. 2014, 94, 2040-2048. [CrossRef] [PubMed]

145. Goyal, A.; Sharma, V.; Upadhyay, N.; Gill, S.; Sihag, M. Flax and flaxseed oil: An ancient medicine \& modern functional food. J. Food Sci. Technol. 2014, 51, 1633-1653. [PubMed]

146. Feres, N.H.; de Lima Reis, S.R.; Veloso, R.V.; Arantes, V.C.; Souza, L.M.I.; Carneiro, E.M.; Boschero, A.C.; Reis, M.A.B.; Latorraca, M.Q. Soybean diet alters the insulin-signaling pathway in the liver of rats recovering from early-life malnutrition. Nutrition $\mathbf{2 0 1 0}$ 26, 441-448. [CrossRef] [PubMed]

147. Ronoh, A.K.; Were, G.M.; Wakhu-Wamunga, F.; Wamunga, J.B. Effect of soybean fortified porridges on the nutritional status of pre-school children 3-5 years old from Western Kenya. J. Food Nutr. Sci. 2017, 5, 155.

148. Akomo, P.; Bahwere, P.; Murakami, H.; Banda, C.; Maganga, E.; Kathumba, S.; Sadler, K.; Collins, S. Soya, maize and sorghum ready-to-use therapeutic foods are more effective in correcting anaemia and iron deficiency than the standard ready-to-use therapeutic food: Randomized controlled trial. BMC Public Health 2019, 19, 806. [CrossRef]

149. Cruz, R.J.; Uy, E.; De Leon, M.N. Randomized controlled trial on the effect of 10 grams Moringa oleifera powder leaves on the level of hemoglobin and hematocrit on infants age 6-9 months. Eur. J. Pediatrics 2016, 175, 1647-1648.

150. Amaglo, N.K.; Bennett, R.N.; Curto, R.B.L.; Rosa, E.A.S.; Turco, V.L.; Giuffrida, A.; Curto, A.L.; Crea, F.; Timpo, G.M. Profiling selected phytochemicals and nutrients in different tissues of the multipurpose tree Moringa oleifera L., grown in Ghana. Food Chem. 2010, 122, 1047-1054. [CrossRef]

151. Glover-Amengor, M.; Aryeetey, R.; Afari, E.; Nyarko, A. Micronutrient composition and acceptability of Moringa oleifera leaffortified dishes by children in Ada-East district, Ghana. Food Sci. Nutr. 2017, 5, 317-323. [CrossRef]

152. Natsir, H.; Wahab, A.W.; Budi, P.; Dali, S.; Arif, A.R. Amino acid and mineral composition of Moringa oleivera leaves extract and its bioactivity as antioxidant. J. Phys. Conf. Ser. 2019, 1317, 012030. [CrossRef]

153. Alain Mune Mune, M.; Nyobe, E.C.; Bakwo Bassogog, C.; Minka, S.R. A comparison on the nutritional quality of proteins from Moringa oleifera leaves and seeds. Cogent Food Agric. 2016, 2, 1213618. [CrossRef]

154. Kou, X.; Li, B.; Olayanju, J.B.; Drake, J.M.; Chen, N. Nutraceutical or pharmacological potential of Moringa oleifera Lam. Nutrients 2018, 10, 343. [CrossRef]

155. Tshingani, K.; Donnen, P.; Mukumbi, H.; Duez, P.; Dramaix-Wilmet, M. Impact of Moringa oleifera Lam. Leaf powder supplementation versus nutritional counseling on the body mass index and immune response of HIV patients on antiretroviral therapy: A single-blind randomized control trial. BMC Complement. Altern. Med. 2017, 17, 1-13. [CrossRef]

156. Barichella, M.; Pezzoli, G.; Faierman, S.A.; Raspini, B.; Rimoldi, M.; Cassani, E.; Bertoli, S.; Battezzati, A.; Leone, A.; Iorio, L. Nutritional characterisation of Zambian Moringa oleifera: Acceptability and safety of short-term daily supplementation in a group of malnourished girls. Int. J. Food Sci. Nutr. 2019, 70, 107-115. [CrossRef]

157. Sultana, S. Nutritional and functional properties of Moringa oleifera. Metabolism Open 2020, 8, 100061. [CrossRef]

158. Wan, M.L.Y.; Ling, K.H.; El-Nezami, H.; Wang, M.F. Influence of functional food components on gut health. Crit. Rev. Food Sci. Nutr. 2019, 59, 1927-1936. [CrossRef]

159. Greiner, T.; Bäckhed, F. Effects of the gut microbiota on obesity and glucose homeostasis. Trends Endocrinol. Metab. 2011, 22, 117-123. [CrossRef] 
160. Le Chatelier, E.; Consortium, M. Richness of human gut microbiome correlates with metabolic markers. Nature 2013, 500, 541-546. [CrossRef] [PubMed]

161. Larsen, N.; Vogensen, F.K.; Van Den Berg, F.W.J.; Nielsen, D.S.; Andreasen, A.S.; Pedersen, B.K.; Al-Soud, W.A.; Sørensen, S.J.; Hansen, L.H.; Jakobsen, M. Gut microbiota in human adults with type 2 diabetes differs from non-diabetic adults. PLoS ONE 2010, 5, e9085. [CrossRef]

162. Karlsson, F.H.; Tremaroli, V.; Nookaew, I.; Bergström, G.; Behre, C.J.; Fagerberg, B.; Nielsen, J.; Bäckhed, F. Gut metagenome in European women with normal, impaired and diabetic glucose control. Nature 2013, 498, 99-103. [CrossRef] [PubMed]

163. Giongo, A.; Gano, K.A.; Crabb, D.B.; Mukherjee, N.; Novelo, L.L.; Casella, G.; Drew, J.C.; Ilonen, J.; Knip, M.; Hyöty, H.; et al. Toward defining the autoimmune microbiome for type 1 diabetes. ISME J. 2011, 5, 82-91. [CrossRef] [PubMed]

164. Qin, J.; Li, Y.; Cai, Z.; Li, S.; Zhu, J.; Zhang, F.; Liang, S.; Zhang, W.; Guan, Y.; Shen, D. A metagenome-wide association study of gut microbiota in type 2 diabetes. Nature 2012, 490, 55-60. [CrossRef]

165. Brown, J.M.; Hazen, S.L. The gut microbial endocrine organ: Bacterially derived signals driving cardiometabolic diseases. Annu. Rev. Med. 2015, 66, 343-359. [CrossRef] [PubMed]

166. Carroll, I.M.; Ringel-Kulka, T.; Keku, T.O.; Chang, Y.-H.; Packey, C.D.; Sartor, R.B.; Ringel, Y. Molecular analysis of the luminal-and mucosal-associated intestinal microbiota in diarrhea-predominant irritable bowel syndrome. Am. J. Physiol. Gastrointest. Liver Physiol. 2011, 301, G799-G807. [CrossRef]

167. Palm, N.W.; De Zoete, M.R.; Cullen, T.W.; Barry, N.A.; Stefanowski, J.; Hao, L.; Degnan, P.H.; Hu, J.; Peter, I.; Zhang, W. Immunoglobulin A coating identifies colitogenic bacteria in inflammatory bowel disease. Cell 2014, 158, 1000-1010. [CrossRef]

168. Saulnier, D.M.; Riehle, K.; Mistretta, T.A.; Diaz, M.A.; Mandal, D.; Raza, S.; Weidler, E.M.; Qin, X.; Coarfa, C.; Milosavljevic, A.; et al. Gastrointestinal microbiome signatures of pediatric patients with irritable bowel syndrome. Gastroenterology 2011, 141, 1782-1791. [CrossRef]

169. Sobhani, I.; Tap, J.; Roudot-Thoraval, F.; Roperch, J.P.; Letulle, S.; Langella, P.; Corthier, G.; Van Nhieu, J.T.; Furet, J.P. Microbial dysbiosis in colorectal cancer (CRC) patients. PLOS ONE 2011, 6, e16393. [CrossRef]

170. Zackular, J.P.; Rogers, M.A.; Ruffin, M.T.t.; Schloss, P.D. The human gut microbiome as a screening tool for colorectal cancer. Cancer Prev. Res. 2014, 7, 1112-1121. [CrossRef] [PubMed]

171. Subramanian, S.; Huq, S.; Yatsunenko, T.; Haque, R.; Mahfuz, M.; Alam, M.A.; Benezra, A.; DeStefano, J.; Meier, M.F.; Muegge, B.D. Persistent gut microbiota immaturity in malnourished Bangladeshi children. Nature 2014, 510, 417-421. [CrossRef] [PubMed]

172. Wu, H.; Tremaroli, V.; Bäckhed, F. Linking microbiota to human diseases: A systems biology perspective. Trends Endocrinol. Metab. 2015, 26, 758-770. [CrossRef] [PubMed]

173. Meijnikman, A.S.; Gerdes, V.E.; Nieuwdorp, M.; Herrema, H. Evaluating causality of gut microbiota in obesity and diabetes in humans. Endocr. Rev. 2018, 39, 133-153. [CrossRef]

174. Clemens, R.; van Klinken, B.J.-W. The future of oats in the food and health continuum. Br. J. Nutr. 2014, 112, S75-S79. [CrossRef] [PubMed]

175. Parikh, M.; Maddaford, T.G.; Austria, J.A.; Aliani, M.; Netticadan, T.; Pierce, G.N. Dietary flaxseed as a strategy for improving human health. Nutrients 2019, 11, 1171. [CrossRef]

176. David, L.A.; Maurice, C.F.; Carmody, R.N.; Gootenberg, D.B.; Button, J.E.; Wolfe, B.E.; Ling, A.V.; Devlin, A.S.; Varma, Y.; Fischbach, M.A. Diet rapidly and reproducibly alters the human gut microbiome. Nature 2014, 505, 559-563. [CrossRef]

177. Rose, D.J. Impact of whole grains on the gut microbiota: The next frontier for oats? Br. J. Nutr. 2014, 112, S44-S49. [CrossRef]

178. Clemens, R.; van Klinken, B.J.-W. Oats, more than just a whole grain: An introduction. Br. J. Nutr. 2014, 112, S1-S3. [CrossRef] [PubMed]

179. Jones, M.L.; Martoni, C.J.; Prakash, S. Cholesterol lowering and inhibition of sterol absorption by Lactobacillus reuteri NCIMB 30242: A randomized controlled trial. Eur. J. Clin. Nutr. 2012, 66, 1234-1241. [CrossRef]

180. Marchesi, J.R.; Adams, D.H.; Fava, F.; Hermes, G.D.A.; Hirschfield, G.M.; Hold, G.; Quraishi, M.N.; Kinross, J.; Smidt, H.; Tuohy, K.M. The gut microbiota and host health: A new clinical frontier. Gut 2016, 65, 330-339. [CrossRef] [PubMed]

181. Eichholzer, M.; Richard, A.; Nicastro, H.L.; Platz, E.A.; Linseisen, J.; Rohrmann, S. Urinary lignans and inflammatory markers in the US National Health and Nutrition Examination Survey (NHANES) 1999-2004 and 2005-2008. Cancer Causes Control 2014, 25, 395-403. [CrossRef]

182. Senizza, A.; Rocchetti, G.; Mosele, J.I.; Patrone, V.; Callegari, M.L.; Morelli, L.; Lucini, L. Lignans and gut microbiota: An interplay revealing potential health implications. Molecules 2020, 25, 5709. [CrossRef]

183. Lemos, J.R.N.; de Alencastro, M.G.; Konrath, A.V.; Cargnin, M.; Manfro, R.C. Flaxseed oil supplementation decreases C-reactive protein levels in chronic hemodialysis patients. Nutr. Res. 2012, 32, 921-927. [CrossRef] [PubMed]

184. Gaya, P.; Medina, M.; Sánchez-Jiménez, A.; Landete, J.M. Phytoestrogen metabolism by adult human gut microbiota. Molecules 2016, 21, 1034. [CrossRef]

185. Kezimana, P.; Dmitriev, A.A.; Kudryavtseva, A.V.; Romanova, E.V.; Melnikova, N.V. Secoisolariciresinol diglucoside of flaxseed and its metabolites: Biosynthesis and potential for nutraceuticals. Front. Genet. 2018, 9, 641. [CrossRef]

186. Quartieri, A.; García-Villalba, R.; Amaretti, A.; Raimondi, S.; Leonardi, A.; Rossi, M.; Tomàs-Barberàn, F. Detection of novel metabolites of flaxseed lignans in vitro and in vivo. Mol. Nutr. Food Res. 2016, 60, 1590-1601. [CrossRef] 
187. Wang, C.-Z.; Ma, X.-Q.; Yang, D.-H.; Guo, Z.-R.; Liu, G.-R.; Zhao, G.-X.; Tang, J.; Zhang, Y.-N.; Ma, M.; Cai, S.-Q. Production of enterodiol from defatted flaxseeds through biotransformation by human intestinal bacteria. BMC Microbiol. 2010, 10, 1-9. [CrossRef] [PubMed]

188. Lagkouvardos, I.; Kläring, K.; Heinzmann, S.S.; Platz, S.; Scholz, B.; Engel, K.H.; Schmitt-Kopplin, P.; Haller, D.; Rohn, S.; Skurk, T. Gut metabolites and bacterial community networks during a pilot intervention study with flaxseeds in healthy adult men. Molecular Nutr. Food Res. 2015, 59, 1614-1628. [CrossRef] [PubMed]

189. Muñoz, O.; Fuentealba, C.; Ampuero, D.; Figuerola, F.; Estévez, A.M. The effect of Lactobacillus acidophilus and Lactobacillus casei on the in vitro bioaccessibility of flaxseed lignans (Linum usitatissimum L.). Food Funct. 2018, 9, 2426-2432. [CrossRef]

190. Inoguchi, S.; Ohashi, Y.; Narai-Kanayama, A.; Aso, K.; Nakagaki, T.; Fujisawa, T. Effects of non-fermented and fermented soybean milk intake on faecal microbiota and faecal metabolites in humans. Int. J. Food Sci. Nutr. 2012, 63, 402-410. [CrossRef] [PubMed]

191. Li, T.; Lu, X.; Yang, X. Stachyose-enriched $\alpha$-galacto-oligosaccharides regulate gut microbiota and relieve constipation in mice. J. Agric. Food Chem. 2013, 61, 11825-11831. [CrossRef] [PubMed]

192. An, C.; Kuda, T.; Yazaki, T.; Takahashi, H.; Kimura, B. Caecal fermentation, putrefaction and microbiotas in rats fed milk casein, soy protein or fish meal. Appl. Microbiol. Biotechnol. 2014, 98, 2779-2787. [CrossRef]

193. Gibson, G.R.; Roberfroid, M.B. Dietary modulation of the human colonic microbiota: Introducing the concept of prebiotics. J. Nutr. 1995, 125, 1401-1412. [CrossRef] [PubMed]

194. Dersjant-Li, Y.; Peisker, M. The impact of soy oligosaccharides on digestion and intestinal health in weaning piglets. Livest. Sci. 2010, 134, 187-189. [CrossRef]

195. Miao, S.; Zhao, C.; Zhu, J.; Hu, J.; Dong, X.; Sun, L. Dietary soybean meal affects intestinal homoeostasis by altering the microbiota, morphology and inflammatory cytokine gene expression in northern snakehead. Sci. Rep. 2018, 8, 1-10. [CrossRef]

196. Umu, Ö.C.O.; Mydland, L.T.; Øverland, M.; Press, C.M.; Sørum, H. Rapeseed-based diet modulates the imputed functions of gut microbiome in growing-finishing pigs. Sci. Rep. 2020, 10, 1-12. [CrossRef]

197. Boué, S.; Fortgang, I.; Levy, R.J., Jr.; Bhatnagar, D.; Burow, M.; Fahey, G.; Heiman, M.L. A novel gastrointestinal microbiome modulator from soy pods reduces absorption of dietary fat in mice. Obesity 2016, 24, 87-95. [CrossRef] [PubMed] 